\title{
5-6 Yaş Resimli Çocuk Kitaplarındaki Resim ve İçerik Ögelerinin MEB Okul Öncesi Eğitim Programı Sosyal-Duygusal Alan Kazanım ve Göstergeler Açısından İncelenmesi
}

\author{
Analysis of the Picture and Content Items of the Children's Picture Book for 5-6 \\ Years Old in terms of Social-Emotional Field Outcomes and Indicators in MEB \\ Preschool Education Program
}

\author{
Endam Düzyol* ${ }^{*}$, Zeynep Gülüm** ${ }^{*}$ Özgenur Korkmaz ${ }^{* * *}$, Şerife Iraz Ün ${ }^{* * * *}$ ve Günseli \\ Yıldırım*****
}

$\ddot{O} z$

Amaç: Bu çalışmada, 5-6 yaş okul öncesi dönem resimli çocuk kitaplarındaki resim ve içerik ögelerinin MEB 2013 Okul Öncesi Eğitim Programı sosyal-duygusal alan kazanım ve göstergeleri açısından incelenmesi amaçlanmıştır. Yöntem: Çalışma, doküman inceleme yöntemi ile tasarlanmış nitel bir araştırmadır. Çalışmada İzmir ili Bornova ilçesindeki Bornova Mehmet Akif Ersoy Çocuk ve Gençlik Kütüphanesi'nde bulunan 3 farkl yayınevine ait 50 adet 60-72 ay resimli çocuk kitapları incelenmiştir. MEB 2013 Okul Öncesi Ĕ̈itim Programı sosyalduygusal gelişim alanında yer alan kazanım ve göstergeler kriter olarak belirlenmiş, veri toplama aracı olarak kullanılmıştır. Çalışmanın analiz kısmında çalışmayı yürüten beş araştırmacı, resimli çocuk kitaplarını bireysel olarak programda yer alan sosyal-duygusal alan kazanım ve göstergelerine göre resim ve içerik ögeleri açısından değerlendirmiştir. Elde edilen veriler frekans ve yüzde değerleri ile analiz edilmiştir. Çalışmada araştırmacılar arasındaki güvenirliği hesaplamak için Miles ve Huberman'ın formülü kullanılmış ve uyum 0,92 bulunmuştur. Bulgular: Çalışmada resimli çocuk kitaplarının resim ve içerik ögelerinde "Bir olay ya da durumla ilgili olarak başkalarının duygularını açıklar." kazanımına en üst seviyede yer verilirken; "Atatürk ile ilgili etkinliklerde sorumluluk alır." kazanımına hiç ver yerilmediği sonucuna ulaşılmıştır. Sonuç: Araştırmanın sonucunda elde edilen veriler okul öncesi dönem çocuklarına yönelik resimli çocuk kitaplarında sıklıkla yer verilen kazanımlar gibi hiç yer verilmeyen kazanımları içeren nitelikli kitapların arttırılması konusunda çalışmalar yapılması

\footnotetext{
*Dokuz Eylül Üniversitesi, İzmir, Türkiye. E-posta: endamduzyo197@ gmail.com

Dokuz,Eylül University, İzmir,Turkey.E-mail: endamduzyol97@gmail.com

** Dokuz Eylül Üniversitesi, İzmir, Türkiye. E-posta: gulum.zeynep10@gmail.com

Dokuz.Eylül University, İzmir, Turkey.E-mail: gulum.zeynep10@gmail.com

${ }^{* * *}$ Dokuz Eylül Üniversitesi, İzmir, Türkiye. E-posta: ozgenurrkorkmazz13@gmail.com

Dokuz Eylül University, İmir, Turkey.E-mail: ozgenurrkorkmazz13@gmail.com

**** Dokuz Eylül Üniversitesi, İzmir, Türkiye. E-posta: irazserife@ hotmail.com

Dokuz,Eylül University, İzmir, Turkey.E-mail: irazserife@hotmail.com

***** Dokuz Eylül Üniversitesi, İzmir, Türkiye. E-posta: gunseli.girgin@ deu.edu.tr Dokuz Eylül University, İmir,Turkey.E-mail: gunseli.girgin@deu.edu.tr
}

Geliş Tarihi - Received: 31.03.2021

Kabul Tarihi - Accepted: 03.06.2021

Yayımlanma Tarihi - Published: 30.06.2021 
gerektiğini göstermektedir. Özgünlük: Literatürde resimli çocuk kitaplartnın içerik ögelerini sosyal-duygusal alan açısından inceleyen çalışmaların sinırlı sayıda olduğu bilinmektedir. Resimli çocuk kitaplarının resim ögelerini ise sosyal-duygusal alan açısından inceleyen herhangi bir çalışma olmadı̆̆ bilinmektedir. Bu bağlamda yapılan çalışmada resimli çocuk kitaplarındaki resim ve içerik ögeleri sosyal-duygusal alan açısından incelenmiştir. Bu nedenle çalışmanin literatüre katkl săglayacağı düşünülmektedir.

Anahtar Sözcükler: MEB 2013 okul öncesi eğitim programi; okul öncesi dönem; sosyalduygusal gelişim; kazanım ve göstergeler; resimli çocuk kitaplarl; resim ögeleri; içerik ögeleri.

\begin{abstract}
Objective: The aim of this study is to examine the picture and content elements in 5-6 years old preschool children picture books in terms of social-emotional field outcomes and indicators of the Ministry of National Education 2013 Preschool Education Program. Method: The study is a qualitative research designed with document review method. The study examined 50 children's 60 - 72-month picture books belonging to 3 different publishing houses in the Bornova Mehmet Akif Ersoy Çocuk ve Gençlik Library in Bornova district of Izmir province. Outcomes and indicators in the field of social-emotional development of Ministry of National Education 2013 Preschool Education Program were determined as criteria and were used as a data collection tool. Five researchers who conducted the study in the analysis part of the study evaluated illustrated children's books individually according to the social-emotional field outcomes and indicators in the program in terms of their pictures and content elements. The obtained data were analyzed with frequency and percentage values. In the study, Miles and Huberman's formula was used to calculate the reliability among the researchers and the concordance was found to be 0,92. Results: In the study, it was concluded that in the pictures and content items of illustrated children's books, while the highest level of importance is given to this learning outcome which is "Describes the feelings of others about an event or situation."; the learning outcome of "Takes responsibility in activities related to Atatürk" is not mentioned. Implications: The data obtained as a result of the study show that studies should be carried out to increase the quality books that include gains that are not included at all, like those that are frequently included in picture children's books for preschool children. Originality: It is known that there are limited number of resources which examine the content elements of illustrated children's books in terms of social-emotional field in the literature. It is also known that there is no study examining the visual elements of illustrated children's books in terms of social-emotional field.
\end{abstract}

Keywords: The Ministry of National Education [MONE] 2013 Preschool Education; preschool period; social-emotional development; outcomes and indicators; illustrated children's books; picture elements; content elements.

\title{
Giriş
}

İnsan yaşamının en önemli dönemlerinden birini oluşturan, 0-8 yaş dönemini kapsayan ve kişiliğin yapı taşlarının oluştuğu erken çocukluk dönemi çocukların bilişsel, öz bakım, dil, motor, sosyal-duygusal becerilerinin gelişimlerinde önemli bir yere sahiptir (Gönen, Yazıcı, Aydos, Öztürk ve Akbaş, 2014). Erken çocukluk döneminin çocukların gelişimine etkisi 
5-6 Yaş Resimli Çocuk Kitaplarındaki Resim ve İçerik Ögelerinin MEB Okul Öncesi Eğitim Programı SosyalDuygusal Alan Kazanım ve Göstergeler Açısından İncelenmesi

Analysis of the Picture and Content Items of the Children's Picture Book for 5-6 Years Old in terms of SocialEmotional Field Outcomes and Indicators in MEB Preschool Education Program

düşünüldüğünde bu dönemde onlara nitelikli ortamlar sunulmasının önemi bilinmektedir (Eliason ve Jenkins, 2003).

Sosyal-duygusal gelişim, kişilik oluşumunda ve çocuğun benimsediği değerler için de oldukça önemlidir (Kandır ve Alpan, 2008). Sosyal-duygusal gelişimleri desteklendikçe bireyler, kendi haklarını söyleme, başkalarının haklarına saygı gösterme, gerektiğinde başkalarından yardım alma ve başkalarına yardım etme, duygu ve düşüncelerini rahatlıkla ifade edebilme, çevresiyle etkili iletişim kurma gibi birçok beceriyi kazanır (Kapıkıran, İvrendi ve Adak, 2006). Bununla ilgili olarak okul öncesi dönemde çocukların o dönemdeki ve gelecekteki sosyal-duygusal becerileri arasındaki ilişkiye bakılan bir araştırmada bu dönemde kazanılan becerilerin gelecekteki eğitimleri, zararlı alışkanlıkları kullanma durumları, ruhsal sağlıkları gibi konuları etkilediği görülmüştür (Jones, Greenberg ve Crowley, 2015). Çocuklara tüm bu alışkanlıklar ve becerileri kazandırabilmek için çeşitli uyaranları içine alan zengin bir çevre sunulması büyük bir önem taşır. Zengin ortamda bulunan kitaplar, çocukların sosyal-duygusal becerileri kazanmasında ve insan ilişkilerini geliştirmesinde en nitelikli araçlardır (Özen, 2020).

Çocuk kitaplarının çocuğu eğlendirerek eğiten bir işlevi vardır (Şirin, 1998). Bu kitapların amacı, okumayı seven ve bunu alışkanlığa dönüştürmüş bireyler yetiştirerek okuma kültürü kazandırmaktır. Erken çocukluk döneminde çocuğun edinmiş olduğu kitap kültürü onun araştırmayı ve sorgulamayı seven, yaratıcı birey olarak yetişmesine fırsat sağlamaktadır (Bilgin, 2011). Kitaplarla erken yaşta tanışan çocuk, kendi duygu ve düşüncelerinin farkına varabilen, başkalarını anlayabilen ve kendini onların yerine koyabilen olumlu bir kişilik geliştirir (Çakmak Güleç ve Geçgel, 2015). Çocuk edebiyatı, çocuğun iç dünyasına seslenerek merak ettikleri durumları keşfetmelerini sağlar. Çocuğun çevresini tanımasına ve duyarlılığını artırmasına destek olur. Çocuğun evrensel ve kültürel değerlerin farkına varmasını sağlayarak dünya hakkındaki bilgilerini geliştirir (Baş, 2015). Yaşama, insana, doğaya ve tüm canlılara sevgi besleyen; benliği ve toplum ile barışık, saygılı, adaletli bireyler kazandırmada çocuk edebiyatı kritik bir öneme sahiptir (Sever, 2013, s. 199).

Çocuklar, kişiliklerini geliştirmede yaşamlarının ilk yıllarındaki deneyimlerine başvurmaktadırlar. Bu nedenle erken çocukluktaki yaşantılar çok önemlidir (Gülpınar, 2010, s. 56). Bu yaştaki çocuklar okuma-yazma becerisine sahip olmadığı için kitap deneyimlerini yetişkinler aracılığı ile edinmektedirler. Bunun yanında aile içerisinde çocuklarla yapılan kitap okuma etkinlikleri aile içi iletişimi arttırarak, aile üyeleri arasında duygusal bağı güçlendirmektedir. Böylelikle çocuk toplum içerisinde kendisini ifade etme becerisi geliştirmekte ve kitaplardan edindiği bilgiler ile kendisine yeni tecrübeler kazandırmaktadır (Pekdoğan, 2017).

Çocuk kitapları, okul öncesi dönemdeki çocukların, karakter gelişimlerini, bilişsel olarak bağlantı kurmalarını destekleyen, sosyalleşmelerini ve dili etkili bir şekilde kullanabilmelerini sağlayan, çeşitli alanlarda gelişmesine yardımcı olan etkili bir eğitim aracıdır (Bulut ve Kuşdemir, 2013). Çocuğu merkeze alan ve destekleyen kitaplar yazılırken çocuğun yaşına, gelişim ilkelerine dikkat etmek, onun ilgileri doğrultusunda ilerlemek gerekir (Huck ve Kiefer, 2003, s. 15). Bu nedenle, çocuklar için dikkat edilmesi gereken bu kriterlere göre çocuk kitaplarını, 0-3 yaşa yönelik hazırlanmış, içerisinde bir tarafında resim diğer tarafında resmi temsil eden sözcüğü içeren ABC kitapları, aynı zamanda oyun oynarken de kullanabildikleri 
oyuncak kitaplar ve resimli çocuk kitapları olarak 3 türe ayırabiliriz (Sever 2005; Turgut Bayram 2009; Ural 2013). Resimli çocuk kitaplarında metnin içeriği kadar resimlerin etkililiği de önemli bir rol oynamaktadır (Gülpınar, 2010, s. 56). Resimli çocuk kitaplarının çocuklara katkıları düşünüldüğünde bu kitapların sosyal-duygusal alandaki birçok becerinin kazanılması ve bunların geliştirilmesinde nitelikli bir araç oldukları söylenebilir (Aram ve Aviram, 2009; Farris ve Fuhler, 1994). Bu araç sayesinde çocuklar yeni keşfetmeye başladığı çevresini anlamlandırma, sosyal yaşamda büyük bir yeri olan sorumluluk, arkadaşlık, yardımlaşma gibi birçok kavramı kazanabilme imkânı bulur (Çılgın, 2006; Çakmak Güleç ve Geçgel, 2006; Aral, 2008). Nitelikli resimli çocuk kitapları, çocukların kendi deneyimlerini elde etmelerine fırsat vererek kendi kültürlerini ve diğer kültürleri keşfetmelerine imkân sunar. Resimli çocuk kitaplarındaki çeşitli karakterler aracılığıyla çocukların yaratıcılıkları gelişir. Paylaşma, empati kurma, sevgi, saygı, hoşgörü gibi davranışlar resimli çocuk kitapları aracılığıyla çocuklara aktarılır (Temple, Martinez ve Yokota, 2006). Resimli çocuk kitapları zengin yaşantılar sunarak çocukların eleştirel düşünme ve problem çözme gibi birçok becerilerine çok yönlü şekilde katkıda bulunur (Güleryüz, 2006). Resimli çocuk kitapları çocukların öğrenmelerini sağladığı, çocuğun gelişimini destekleyen tüm alanları pozitif şekilde etkilediği ve dünyayı farklı gözden görmelerini sağladığı için erken çocukluk dönemindeki çocuklar için önemli bir araçtır. Bu yüzden okul öncesi eğitim veren kurumlarda sosyal duygusal alanı geliştirmek için resimli çocuk kitaplarının yer alması gerekmektedir (Sildir ve Tüfekci Akcan, 2018).

Demircan (2006), TÜBİTAK (Türkiye Bilimsel ve Teknolojik Araştırma Kurumu)'ın yayımlamış olduğu 34 adet çocuk kitabını, araştırmacının hazırladığı form aracılığıyla dış yapı ve içyapı kıstaslarına yönelik değerlendirmiştir. Analiz sonucunda, yazar-kitap bilgileri bölümünde bütün eserlerin; konu-plan bölümünde 33 eserin; tasarım-düzenleme bölümünde 31 eserin uygun kıstasları içerdiği tespit edilmiştir. Dil-anlatım bölümünde 23 eserin ve resimlendirme bölümünde ise 20 eserin geçerli kıstasları taşıdığı görülmüştür. Yapılan araştırmada, TÜBİTAK'ın eserlerinden bazılarının ideal düzeyde olmamasına rağmen çoğunluğunda uygun kıstasların bulunduğu sonucuna ulaşılmıştır. Veziroğlu ve Gönen (2012) tarafından yapılan bir araştırmada 3-6 yaşa yönelik 250 resimli çocuk kitabı 2006 Okul Öncesi Eğitim Programı'ndaki amaç-kazanımlar açısından incelenmiştir. Araştırmanın sonucunda sosyal-duygusal alanın kitaplarda karşılanma oranının tüm gelişim alanları içerisinde en yüksek yüzdede yer aldığı sonucuna ulaşılmıştır. Gönen ve Yılmaz'ın (2018) araştırmasında resimli çocuk kitapları konuları açısından değerlendirilmiştir. Araştırmanın örneklemi, Ankara ilindeki üç halk kütüphanesinin çocuk bölümünde bulunan 1152 resimli çocuk kitabından oluşmaktadır. Araştırmada, sosyal-duygusal alanı geliştiren 760, dil alanını geliştiren 9, doğaüstü konuları barındıran 17, öz bakım becerilerini geliştiren 53, bilişsel alanı geliştiren 313 kitabın bulunduğu tespit edilmiştir. Kitaplarda sevgi, arkadaşlık, yardımlaşma, sorumluluk ve kurallar gibi sosyal gelişim konularının yer aldığı görülmektedir. Sosyal-duygusal gelişim alanını destekleyici nitelikteki kitapların her kütüphanede yer aldığı sonucuna ulaşılmıştır. Yazıcı, Yıldız ve Durmuşoğlu (2018), 3-8 yaş çocuklarına yönelik 2010-2015 yılları arasında oluşturulan resimli çocuk kitaplarını eğitsel açıdan incelemiştir. 37 yayınevinden 300 adet eser değerlendirilmiştir. Eserlerin \%89'unun günümüz Türkçesi ile kaleme alındığı, \%73'ünün çocukların yaratıcılığını desteklediği, \%70'inin ilim ve kültür aktarımında bulunduğu, \%82'sinin yabancı dildeki kelimelerden arındığı, \%88'inin önyargı bulundurmadığı ve \%71'inin dil becerilerinin gelişimine destek olduğu tespit edilmiştir. Ayrıca kitaplarda şiddet ögesi içeren ifadelere 
5-6 Yaş Resimli Çocuk Kitaplarındaki Resim ve İçerik Ögelerinin MEB Okul Öncesi Eğitim Programı SosyalDuygusal Alan Kazanım ve Göstergeler Açısından İncelenmesi

Analysis of the Picture and Content Items of the Children's Picture Book for 5-6 Years Old in terms of Social-

rastlanmamıştır. Kılınçcı ve Can (2020) tarafından yapılan bir araştırmada da 36-72 ay grubu çocuklara yönelik Uşak İl Halk Kütüphanesi'nde yer alan 56 resimli hikâye kitabındaki karakterlerin 2013 Okul Öncesi Eğitim Programı'ndaki sosyal-duygusal alan kazanım ve göstergeleri ne düzeyde karşıladığı belirlenmeye çalışılmıştır. Araştırmanın sonucunda değerlendirilen kitaplarda "Farklı kültürel özellikleri açıklar.”, "Atatürk ile ilgili konuşur.” ve "Sanat eserlerinin değerini fark eder.” kazanımlarına hiç yer verilmediği sonucuna ulaşılmıştır.

MEB 2013 yılı Okul Öncesi Eğitim Programı’nda çocuklara kazandırılması gereken sosyal-duygusal becerilere "Sosyal-duygusal kazanımlar" başlı̆ğ altında 17 kazanım ve 53 gösterge olarak yer verilmiştir. Bu çalışmada, "5-6 yaş okul öncesi dönem resimli çocuk kitaplarındaki resim ve içerik ögelerinin MEB 2013 Okul Öncesi Eğitim Programı sosyalduygusal alan kazanım ve göstergeleri açısından incelenmesi” amaçlanmıştır. Bu doğrultuda aşağıda bulunan sorulara yanıt aranmıştır:

1. 5-6 yaş okul öncesi dönem resimli çocuk kitaplarındaki resim ögeleri, MEB 2013 Okul Öncesi Eğitim Programı sosyal-duygusal alan kazanım ve göstergelerini içermekte midir?

2. 5-6 yaş okul öncesi dönem resimli çocuk kitaplarındaki içerik ögeleri, MEB 2013 Okul Öncesi Eğitim Programı sosyal-duygusal alan kazanım ve göstergelerini içermekte midir?

3. 5-6 yaş okul öncesi dönem resimli çocuk kitaplarında, MEB 2013 Okul Öncesi Eğitim Programı sosyal-duygusal alan kazanım ve göstergelerinin bulunması bakımından resim ve içerik ögeleri arasında farklılık var mıdır?

\section{Yöntem}

\section{Araştırmanın Modeli}

Çalışma, nitel araştırma yöntemlerinden biri olan doküman analizi yöntemi kullanılarak yapılmıştır. Doküman analizi, bağlama ilişkin olay ve olgu ile ilgili bilgileri içeren yazılı araçların bütüncül bir şekilde analiz edilmesidir (Yıldırım ve Şimşek, 2011, s. 187). Ayrıca bu çalışmada İzmir ili Bornova ilçesindeki Bornova Mehmet Akif Ersoy Çocuk ve Gençlik Kütüphanesi'nde bulunan 3 farklı yayınevine ait kitaplar incelendiğinden, çalışma, kapsamı itibari ile örnek olay niteliği taşımaktadır.

\section{Çalışma Grubu}

Çalışma grubu, İzmir ili Bornova ilçesindeki Bornova Mehmet Akif Ersoy Çocuk ve Gençlik Kütüphanesi'nde bulunan 3 farklı yayınevine ait 50 adet 60-72 ay resimli çocuk kitaplarından oluşmaktadır. Nitel araştırmalarda amaç, evrene genellemeler yapmak değil, konuyu detaylı şekilde çalışarak bir kapsam oluşturmaktır (Yıldırım ve Şimşek, 2016). Buradan yola çıkarak bu araştırmadaki çalışma grubu "amaçlı örnekleme" yöntemleri içerisinde yer alan "ölçüt örnekleme" olarak seçilmiştir.

Amaçlı örnekleme yöntemi, zengin içeriğin yer aldığı konuları derinlemesine inceleyerek çalışılmasına ve olguların keşfedilip açıklanmasına olanak sağlar. Ölçüt örnekleme ise, amaçsal örnekleme yönteminin bir türüdür. Araştırmacı tarafından araştırmaya konu olacak kıstaslar önceden belirlenir. Belirlenen kıstasları içeren araştırmalar yapılır (Yıldırım ve Şimşek, 2016). 
Bu bağlamda araştırmacıların kitap seçiminde göz önünde bulundurduğu ölçütler; kitapların 60-72 ay erken çocukluk dönemine yönelik olması, kitapların resimli çocuk kitabı özelliğini barındırması, daha detaylı inceleme yapılması ve konuya netlik kazandırması amacıyla belirlenen yayınevlerinin seri özelliği taşıyan ve piyasada bulunan ancak çok fazla incelenmeyen kitapların seçilmesidir.

\section{Veri Toplama Araçlart}

Bu çalışmada kriter olarak MEB 2013 Okul Öncesi Eğitim Programı sosyal-duygusal alanda bulunan kazanım ve göstergeler belirlenmiştir (MEB, 2013). Seçilen kitaplarda bu göstergelerin hangilerinin bulunduğu incelenmiştir.

\section{Veri Toplama Süreci}

Çalışma için veriler elde edilirken üç aşamadan geçilmiştir. Birinci aşamada resimli çocuk kitaplarına ulaşabilmek için farklı kütüphanelerle görüşülerek çalışmada kullanılacak resimli çocuk kitaplarını içeren Bornova Mehmet Akif Ersoy Çocuk ve Gençlik Kütüphanesi'nden gerekli izinler alınmıştır. İkinci aşamada belirlenen kütüphaneye gidilmiş, kütüphanede bulunan resimli çocuk kitapları yaş grubu, yayınevi gibi değişkenler açısından değerlendirilmiştir. Değerlendirme sonunda üç yayınevine karar verilmiş, yayınevlerinin 60-72 aylık çocuklara yönelik 50 adet resimli çocuk kitabı incelemeye alınmıştır. Üçüncü aşama, belirlenen resimli çocuk kitaplarının resim ve içerik ögelerinin MEB sosyal-duygusal alandaki kazanım ve göstergeler açısından incelenmesini ve verilerin analizini oluşturmaktadır.

\section{Verilerin Analizi}

Araştırmalarda araştırmacıların konu hakkında uzman görüşüne başvurması araştırmanın iç geçerliğini arttıran bir durumdur (Denzin ve Lincoln, 2008; Sandelowski, 1986). Bu çalışmada da veri toplama süreci bittikten sonra araştırmacılar alanında uzman kişilerden incelenen resimli çocuk kitaplarındaki resim ve içerik ögelerinin kazanım-göstergelere uygunluğu hakkında görüşlerini alarak, araştırmanın iç geçerliğini arttırmışlardır. Çocuk kitaplarını, çalışmayı yürüten beş araştırmacı birbirinden bağımsız olarak MEB sosyal-duygusal alan kazanım ve göstergelerine göre değerlendirmiştir. Araştırmacılar, daha sonra kendi bireysel değerlendirmelerini birbirleri ile karşılaştırmışlardır. Böylece, araştırmacıların arasındaki uyumluluk hesaplanmıştır. Çalışmada, araştırmacılar arası güvenirliği hesaplamak amacıyla "Miles ve Huberman (1994)"'1n "Güvenirlik = Görüş Birliği / Görüş Birliği + Görüş Ayrılığı" formülü uygulanmıştır. Elde edilen sonuca göre araştırmacılar arasında uyum yüzdesi \%92,33 bulunmuştur. Bu işlem sırasında ilk olarak kitap okunmadan sadece resimler analiz edilerek sosyal-duygusal alan kazanım ve göstergelerine göre işaretlenmiştir. Analiz sırasında incelenen kitapta yer alan resimler araştırmacılar tarafından hangi kazanım-göstergeye uygun görüldüyse o madde işaretlenmiştir. Analizi yapılan kitapta bulunan resimler her gösterge için tek tek incelenmiştir. Daha sonra kitaptaki metinler okunarak analiz edilmiştir. Çocuk kitaplarındaki resim ögelerinin incelenmesi esnasinda kitaplarda bulunan metinlerin resimleri yorumlamaya dair bir önyargı oluşturmamasına dikkat edilmiştir. Değerlendirme yapılırken sosyal-duygusal alanda yer alan 53 göstergenin her biri ayrı bir madde olarak ele alınmıştır. Resimli çocuk kitaplarının resim ve içerik ögeleri her gösterge için ayrı ayrı incelenmiştir. Resimli çocuk kitaplarında resim ve içerik ögelerinin içerdiği maddeye göre MEB sosyal-duygusal alandaki 
5-6 Yaş Resimli Çocuk Kitaplarındaki Resim ve İçerik Ögelerinin MEB Okul Öncesi Eğitim Programı SosyalDuygusal Alan Kazanım ve Göstergeler Açısından İncelenmesi

Analysis of the Picture and Content Items of the Children's Picture Book for 5-6 Years Old in terms of SocialEmotional Field Outcomes and Indicators in MEB Preschool Education Program

kazanım ve göstergelere işaret konulmuş, kitapta resim veya içerik ögesinde bulunmayan göstergeler boş bırakılmıştır. Resimli çocuk kitaplarının resim ve içerik ögelerinde bulunan göstergeler işaretlenmiş ve her bir gösterge 1 puan olarak değerlendirilmiştir. Resimli çocuk kitaplarında bulunmayan göstergeler ise boş bırakılmış ve 0 puan olarak ele alınmıştır. Her kazanımın altında bulunan göstergelerin puanları toplanarak o kazanıma ait toplam puan elde edilmiştir. Kazanım ve göstergelerin kitapların resim ve içerik ögelerinde bulunma sıklıklarına göre frekansı belirlenmiştir. Bu sonuca göre resimli çocuk kitaplarının resim ve içerik ögelerinde MEB sosyal-duygusal alan kazanımlarına ne kadar yer verdiği ortaya konmuştur.

\section{Sinırlılıklar}

1. Bu çalışma İzmir ili Bornova ilçesindeki Bornova Mehmet Akif Ersoy Çocuk ve Gençlik Kütüphanesi'nde bulunan 50 adet 60-72 ay resimli çocuk kitapları ile sınırlıdır.

2. Resimli çocuk kitapları 3 farklı yayınevine aittir ve 2006-2019 yılları arasında yayınlanmıştır.

3. Resimli çocuk kitaplarının sosyal-duygusal gelişime ilişkin değerlendirilmesi MEB 2013 Okul Öncesi Eğitim Programı'ndaki sosyal-duygusal alan kazanım ve göstergeler ile sınırlandırılmıştır.

\section{Bulgular}

Çalışmada yer verilen resimli çocuk kitaplarının resim ve içerik ögelerinde yer alan kazanım ve göstergelerin kitaplarda bulunma oranlarına göre belirlenen frekans ve yüzde değerleri Tablo 1 'de belirtilmiştir.

\section{Tablo 1}

Sosyal-Duygusal Alan Kazanım ve Göstergelerinin Resimli Çocuk Kitaplarında Resim ve İçerik Ögelerine Göre Frekans ve Yüzde Değerleri

\begin{tabular}{|c|c|c|c|c|c|}
\hline Kazanım & Göstergeler & $\begin{array}{r}\text { İçerik } \\
\text { Ögeleri } \\
(\mathrm{f}) \\
\end{array}$ & $\begin{array}{r}\text { İçerik } \\
\text { Ögeleri } \\
(\%) \\
\end{array}$ & $\begin{array}{r}\text { Resim } \\
\text { Ögeleri } \\
\text { (f) } \\
\end{array}$ & $\begin{array}{r}\text { Resim } \\
\text { Ögeleri } \\
(\%) \\
\end{array}$ \\
\hline \multirow{5}{*}{$\begin{array}{l}\text { "K1: Kendisine } \\
\text { özellikleri tanitır." }\end{array}$} & "K1. G1: Adın1/soyadını söyler." & 6 & 1,26 & 2 & 0,50 \\
\hline & "K1. G2: Yaş1nı söyler." & 0 & 0 & 0 & 0 \\
\hline & $\begin{array}{l}\text { "K1. G3: Fiziksel özelliklerini } \\
\text { söyler." }\end{array}$ & 10 & 2,10 & 8 & 2,02 \\
\hline & $\begin{array}{l}\text { "K1. G4: Duyuşsal özelliklerini } \\
\text { söyler." }\end{array}$ & 50 & 10,48 & 49 & 12,34 \\
\hline & K1 Toplam & 66 & 13,84 & 59 & 14,86 \\
\hline \multirow[t]{6}{*}{$\begin{array}{l}\text { "K2: Ailesiyle } \\
\text { özellikleri tanıtır." }\end{array}$} & $\begin{array}{l}\text { "K2. G1: Anne/babasının adın1, } \\
\text { soyadın1, mesleğini vb. söyler." }\end{array}$ & 2 & 0,42 & 0 & 0 \\
\hline & $\begin{array}{l}\text { "K2. G2: Anne/babasının saç } \\
\text { rengi, boyu, göz rengi gibi fiziksel } \\
\text { özelliklerini söyler." }\end{array}$ & 0 & 0 & 0 & 0 \\
\hline & $\begin{array}{l}\text { "K2. G3: Teyze/amca gibi yakın } \\
\text { akrabalarının isimlerini söyler." }\end{array}$ & 0 & 0 & 0 & 0 \\
\hline & $\begin{array}{l}\text { "K2. G4:Telefon numarasin1 } \\
\text { söyler." }\end{array}$ & 2 & 0,42 & 0 & 0 \\
\hline & "K2. G5: Evinin adresini söyler." & 3 & 0,63 & 0 & 0 \\
\hline & K2 Toplam & 7 & 1,47 & 0 & 0 \\
\hline $\begin{array}{l}\text { "K3: Kendini yaratıc1 } \\
\text { yollarla ifade eder." }\end{array}$ & $\begin{array}{l}\text { "K3. G1: Duygu, düşünce ve } \\
\text { hayallerini özgün yollarla ifade } \\
\text { eder." }\end{array}$ & 11 & 2,31 & 15 & 3,78 \\
\hline
\end{tabular}




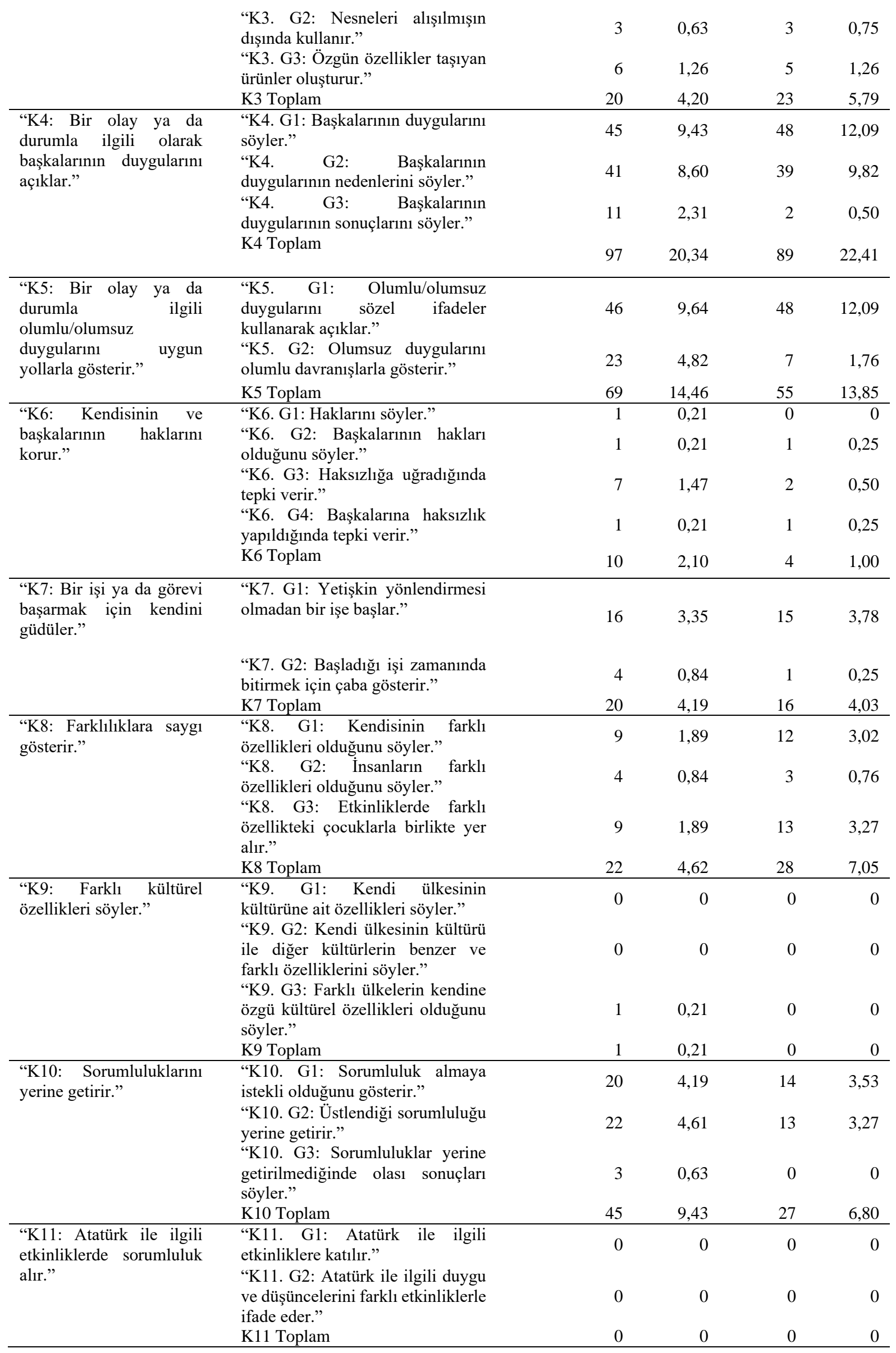


5-6 Yaş Resimli Çocuk Kitaplarındaki Resim ve İçerik Ögelerinin MEB Okul Öncesi Eğitim Programı SosyalDuygusal Alan Kazanım ve Göstergeler Açısından İncelenmesi

Analysis of the Picture and Content Items of the Children's Picture Book for 5-6 Years Old in terms of SocialEmotional Field Outcomes and Indicators in MEB Preschool Education Program

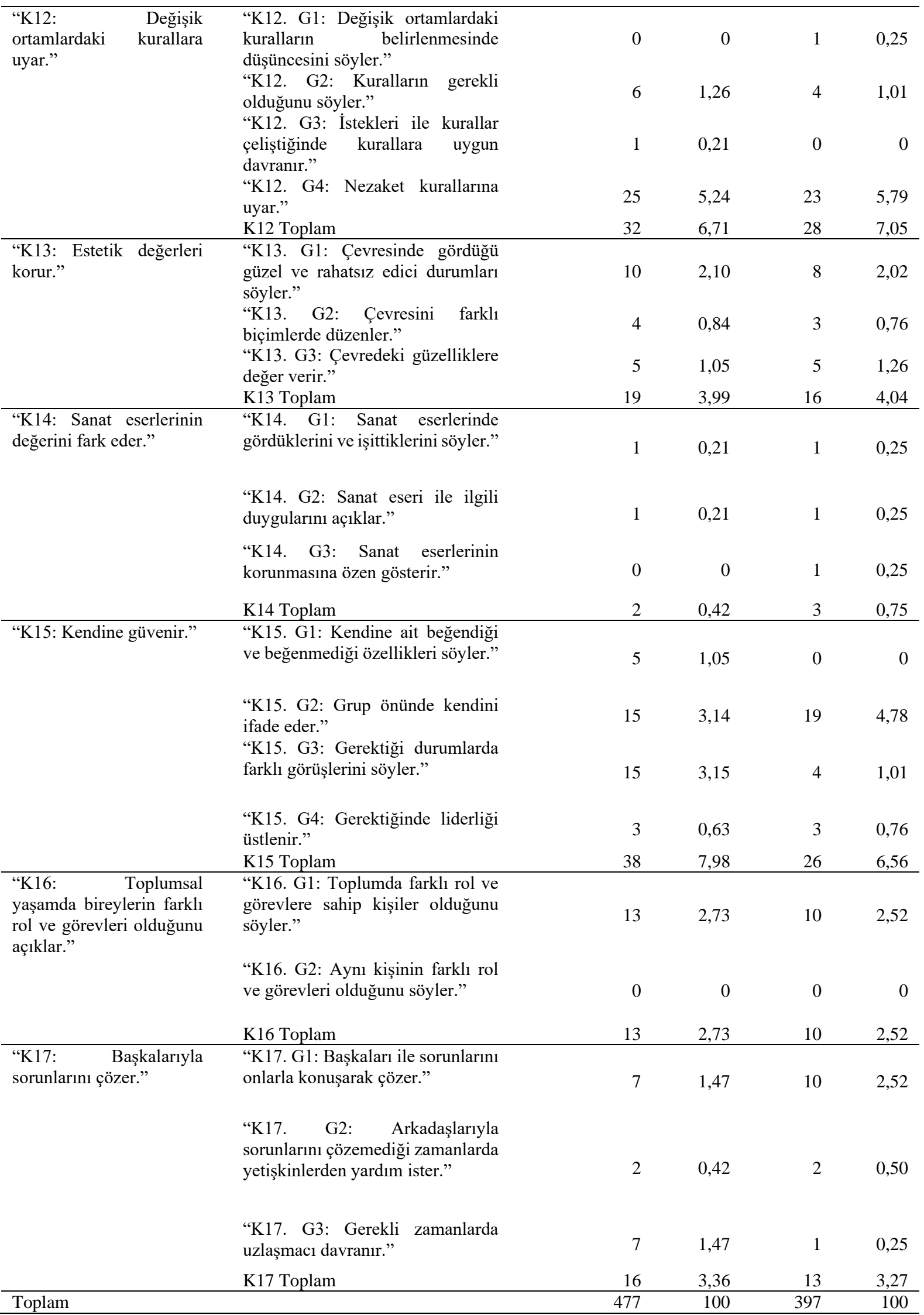


Tablo 1 incelendiğinde resimli çocuk kitaplarının resim ve içerik ögelerinde yer alan her kazanım ve göstergeye ait frekans ve yüzde değerleri görülmektedir. Bu verilere bakıldığında resimli çocuk kitaplarının resim ve içerik ögelerinde sosyal-duygusal alan kazanım ve göstergelerinin hepsine yer verilmediği gözlenmektedir.

Resimli çocuk kitaplarında içerik ögelerinde sosyal-duygusal kazanıma yer verilme yüzdeleri en yüksek düzeyden en düşük düzeye şu şekilde sıralanmaktadır: K4 "Bir olay ya da durumla ilgili olarak başkalarının duygularını açıklar." (\%20,34), K5 "Bir olay ya da durumla ilgili olumlu/olumsuz duygularını uygun yollarla gösterir." (\%14,46), K1 "Kendisine ait özellikleri tanıtır." (\%13,84), K10 "Sorumluluklarını yerine getirir." (\%9,43), K15 "Kendine güvenir.” (\%7,98), K12 “Değişik ortamlardaki kurallara uyar.” (\%6,71), K8 "Farkl11ıklara sayg1 gösterir.” $(\% 4,62), \mathrm{K} 3$ "Kendini yaratıcı yollarla ifade eder.” $(\% 4,20), \mathrm{K} 7$ "Bir işi ya da görevi başarmak için kendini güdüler." (\%4,19), K13 "Estetik değerleri korur.” $(\% 3,99)$, K17 "Başkalarıyla sorunlarını çözer." $(\% 3,36), \mathrm{K} 16$ "Toplumsal yaşamda bireylerin farklı rol ve görevleri olduğunu açıklar.” (\%2,73), K6 "Kendisinin ve başkalarının haklarını korur." $(\% 2,10)$, K2 “Ailesiyle ilgili özellikleri tanıtır." $(\% 1,47)$, K14 "Sanat eserlerinin değerini fark eder." (\%0,42), K9 "Farklı kültürel özellikleri söyler." (\%0,21). Burada en dikkati çeken nokta "K11: Atatürk ile ilgili etkinliklerde sorumluluk alır" kazanımının "G1: Atatürk ile ilgili etkinliklere katılır.” ve “G2: Atatürk ile ilgili duygu ve düşüncelerini farklı etkinliklerle ifade eder” göstergelerine hiç yer verilmemiş olmasıdır.

Resimli çocuk kitaplarında resim ögelerinde sosyal-duygusal kazanıma yer verilme yüzdeleri en yüksek düzeyden en düşük düzeye şu şekilde sıralanmaktadır: K4 "Bir olay ya da durumla ilgili olarak başkalarının duygularını açıklar." $(\% 22,41)$, K1 "Kendisine ait özellikleri tanitır." (\%14,86), K5 "Bir olay ya da durumla ilgili olumlu/olumsuz duygularını uygun yollarla gösterir." (\%13,85), K12 "Değişik ortamlardaki kurallara uyar.” ve K8 "Farklılıklara sayg1 gösterir." (\%7,05), K10 "Sorumluluklarını yerine getirir." (\%6,80), K15 "Kendine güvenir." $(\% 6,56)$, K3 "Kendini yaratıcı yollarla ifade eder." (\%5,79), K13 "Estetik değerleri korur." (\%4,04), K7 "Bir işi ya da görevi başarmak için kendini güdüler.” (\%4,03), K17 "Başkalarıyla sorunlarını çözer." (\%3,27), K16 "Toplumsal yaşamda bireylerin farklı rol ve görevleri olduğunu açıklar.” (\%2,52), K6 “Kendisinin ve başkalarının haklarını korur.” (\%1,00), K14 "Sanat eserlerinin değerini fark eder." $(\% 0,75)$ olarak belirlenmiştir. Bunun yanında K2 “Ailesiyle ilgili özellikleri tanıtır.”, K9 "Farklı kültürel özellikleri söyler.” ve K11 “Atatürk ile ilgili etkinliklerde sorumluluk alır” kazanımlarına hiç yer verilmemiştir.

Çalışmada yer verilen resimli çocuk kitaplarının içerik ögelerinde yer alan kazanım ve göstergelerin bulunduğu kitaplardan alınan örnek cümleler Tablo 2'de sunulmuştur. 
5-6 Yaş Resimli Çocuk Kitaplarındaki Resim ve İçerik Ögelerinin MEB Okul Öncesi Eğitim Programı SosyalDuygusal Alan Kazanım ve Göstergeler Açısından İncelenmesi

Analysis of the Picture and Content Items of the Children's Picture Book for 5-6 Years Old in terms of SocialEmotional Field Outcomes and Indicators in MEB Preschool Education Program

\section{Tablo 2}

Resimli Çocuk Kitaplarında Yer Alan Sosyal-Duygusal Alandaki Kazanım ve Göstergelere İlişkin Örnek Cümleler

\begin{tabular}{|c|c|c|}
\hline Kazanım & Göstergeler & İçerik Ögeleri Örnek Cümle \\
\hline \multirow[t]{4}{*}{ "K1: Kendisine ait özellikleri tanıtır." } & "K1. G1: Adını/soyadını söyler." & $\begin{array}{l}\text { "Ben Lila, bu sihirli kitap ile seyahat } \\
\text { ediyorum ve kitabı okuyanlarla arkadaş } \\
\text { olmayı umuyorum" }\end{array}$ \\
\hline & "K1. G2: Yaşını söyler.” & Gözlenmedi \\
\hline & $\begin{array}{l}\text { "K1. G3: Fiziksel özelliklerini } \\
\text { söyler." }\end{array}$ & $\begin{array}{l}\text { "Kocaman ve güçlü olmayabilirim. Upuzun } \\
\text { da değilim. Tüm hayvanlar içinde, en miniği } \\
\text { benim" }\end{array}$ \\
\hline & $\begin{array}{l}\text { "K1. G4: Duyuşsal özelliklerini } \\
\text { söyler." }\end{array}$ & $\begin{array}{l}\text { "Kardeşim beni kızdırdı. Çok öfkelendim ve } \\
\text { arabamı fırlattım" }\end{array}$ \\
\hline $\begin{array}{l}\text { "K2: Ailesiyle ilgili özellikleri } \\
\text { tanitır." }\end{array}$ & $\begin{array}{l}\text { "K2. G1: Anne/babasının adını, } \\
\text { soyadını, mesleğini vb. söyler." }\end{array}$ & $\begin{array}{l}\text { "Babam kendi adını ve annemin adını tek tek } \\
\text { sordu. Daha önce bunları mutlaka } \\
\text { ezberlemem gerektiğini söylemişti. Ben de } \\
\text { ezberlemiştim ve söyledim" }\end{array}$ \\
\hline
\end{tabular}

"K2. G2: Anne/babasının saç rengi, boyu, göz rengi gibi fiziksel özelliklerini söyler."

"K2. G3: Teyze/amca gibi yakın akrabalarının isimlerini söyler."

"K2.G4: Telefon numarasin söyler."

\section{Gözlenmedi}

Gözlenmedi

"Babam evimizin telefonunu, annemin ve kendisinin telefonlarını söylememi istedi. Daha önce bunları mutlaka ezberlemem gerektiğini söylemişti. Ben de ezberlemiştim ve söyledim"

"K2. G5: Evinin adresini söyler." "Saksağan Çıkmazı No: Altmış yedi sıradan bir apartmandı, çok sakindi”"

"K3: Kendini yaratıc1 yollarla ifade "K3. G1: Duygu, düşünce ve eder." hayallerini özgün yollarla ifade eder."

"Bir baktım, Everest Dağı'nın en dik yamacına tırmandım. Bir baktım sirkteyim, ip üstünde gösterimle gözleri kamaştırdım. Tam Büyük Resif'te suların dibine dalacaktım"

"K3. G2: Nesneleri alışılmışın dışında kullanır."

"Topak, hemen kurumuş yaprakları ve dalları bir araya topladı. Ağacın altında büyük bir tepe oluşturdu. Pamuk, ağaçtan bu yumuşak tepenin üstüne atlayabilirdi”

"K3. G3: Özgün özellikler taşıyan "Tam gece yarısı olunca iki tane küçük cüce ürünler oluşturur." çıkageldi. Ayakkabıcının tezgâhına oturdular ve çalışmaya başladılar. Küçücük parmaklarıyla dikiş yaptılar, deriyi tokmakla dövdüler ve şekil verdiler. Ayakkabıcı için yeni ayakkabilar yaptılar."

\begin{tabular}{|c|c|c|}
\hline \multirow[t]{2}{*}{$\begin{array}{l}\text { "K4: Bir olay ya da durumla ilgili } \\
\text { olarak başkalarının duygularını } \\
\text { açıklar." }\end{array}$} & $\begin{array}{lr}\text { "K4. G1: } & \text { Başkalarının } \\
\text { duygularını söyler." } & \\
\text { "K4G2: } & \text { Başkalarının } \\
\text { duygularının nedenlerini söyler." }\end{array}$ & $\begin{array}{l}\text { "Birinin Furkan'a zarar verdiğinden } \\
\text { korkuyorlarmış." } \\
\text { "Öğretmenim ödevimi temiz tutmadığım için } \\
\text { bana kızd.." }\end{array}$ \\
\hline & $\begin{array}{l}\text { "K4G3: Başkalarının } \\
\text { duygularının sonuçlarını söyler." }\end{array}$ & $\begin{array}{l}\text { "Niçin ağladığını soranlar olmuş ama } \\
\text { annesinin kızacağından korktuğu için } \\
\text { kimseyle konuşmamış." }\end{array}$ \\
\hline \multirow[t]{2}{*}{$\begin{array}{l}\text { "K5: Bir olay ya da durumla ilgili } \\
\text { olumlu/olumsuz duygularını uygun } \\
\text { yollarla gösterir." }\end{array}$} & $\begin{array}{l}\text { "K5. G1: Olumlu/olumsuz } \\
\text { duygularını olumlu sözel ifadeler } \\
\text { kullanarak açıklar." }\end{array}$ & $\begin{array}{l}\text { "Tamam, tamam, anladım. Oyunlar eğlenmek } \\
\text { ve iyi zaman geçirmek için var. Her zaman en } \\
\text { iyi olmam gerekmiyor. Eğlendikçe } \\
\text { kazanıyoruz. Ebe olsak da olmasak da! Ama } \\
\text { körebede en iyi benim değil mi?" }\end{array}$ \\
\hline & $\begin{array}{l}\text { "K5. G2: Olumsuz duygularını } \\
\text { olumlu davranışlarla gösterir." }\end{array}$ & $\begin{array}{l}\text { "Ama koridordaki 1şılar sönük ve mutfak } \\
\text { karanlık." dedim. Arkadaşım: "Olsun, } \\
\text { lambaları açarak giderim. Dönerken de } \\
\text { kapatırım. O zaman her yer aydınlık olur } \\
\text { istersen sen dene. Ben sana buradan } \\
\text { bakıyorum." diye ekledi. Gerçekten de } \\
\text { yapabildim." }\end{array}$ \\
\hline
\end{tabular}




$\begin{aligned} & \text { "K6: Kendisinin ve başkalarının "K6. G1: Haklarını söyler." } \\ & \text { haklarını korur." }\end{aligned}$
$\begin{aligned} & \text { "K6. G2: Başkalarının hakları } \\ & \text { olduğunu söyler." }\end{aligned}$
"K6. G3: Haksılığa uğradığında
tepki verir."
"K6. G4: Başkalarına haksızlık
yapıldığında tepki verir."

Sivrikuyruk: "Bence oylar yanlış sayıldı. Benim oyum bir tane daha fazlaydı. Bakın yere düşmüş"

"Sevgili dostlarım! Artık bizi sıcak ülkelere götürecek yeni bir lider seçme vaktiniz geldi. Şu anda aday olmak isteyen kimse var mı?" diye sordu.

yapıldığında tepki verir."

"Ben de oksijen üretip durdum ama piknik yapan insanlar gelip ormana bir sürü çöp attılar. Sonra da toplamadan gittiler çok kızgınım. Zaten ailem: Artık insanlara faydalı olmasak mı? diye düşünüyorlar dedi üzüntüyle çam ağacı."

"Bu eziyeti hayvancığa kim yapmış olabilir ki? diye sordu. Cevabı ikisi de bilmiyorlard1. Sadece Gönül: Kim olduğunu bilmiyorum ama bunu yapanın çok merhametsiz, kalbi katılaşmış biri olduğu kesin! diye cevap verdi."

"K7: Bir işi ya da görevi başarmak "K7. G1: Yetişkin yönlendirmesi için kendini güdüler." olmadan bir işe başlar."

"K7. G2: Başladığı iși zamanında bitirmek için çaba gösterir.”

\begin{tabular}{ll}
\hline "K8: Farklılıklara sayg1 gösterir.” & "K8. G1: Kendisinin farklı \\
& özellikleri olduğunu söyler."
\end{tabular}

"K8. G2: İnsanların farkl özellikleri olduğunu söyler."

"K8. G3: Etkinliklerde farklı özellikteki çocuklarla birlikte yer alır." $\begin{aligned} & \text { "K9: Farklı kültürel özellikleri } \\ & \text { söyler." }\end{aligned}$
kültürüne ait özellikleri söyler."

"Kartopu oynamay1 bitirdiklerinde, Elif kiraladıkları kayakları denemek istedi. Kayak botlarını uzun kayaklara geçirdi ve kayak sopalarını eline aldı. Böyle ayakta durmak bile çok zordu doğrusu! Elif ayakta durabilmeyi zar zor becerdi."

"Yarışma başladı ve her hayvana altı ay zaman verildi. Zaman hızla geçti. Üç hayvan da gece gündüz çalışmaya başladı."

"Fatih, sene başından beri Dilara'nın kendisiyle konuşmaktan kaçındığını üzüntüyle fark etmiști. Dilara'nın bu davranışının tekerlekli sandalyede olması ile bağlantılı olduğunu düşünüyordu."

"Ayşe çok zayıf. Yağız ise çok şişman."

"Yeni bir hayat başladı o günden sonra Koca Ayı çoğu zaman birlikteydi tavşanlarla."

\section{Gözlenmedi} "K9. G2: Kendi ülkesinin kültürü ile diğer kültürlerin

Gözlenmedi

benzer ve farklı özelliklerini söyler."

"K9. G3: Farklı ülkelerin kendine özgü kültürel özellikleri olduğunu söyler."

"Gardırobun üzerindeki kırmızı şey bir Meksika şapkasıydı. Zeynep koşarak şapkayı annesine göstermeye gitti."

\begin{tabular}{|c|c|c|c|}
\hline \multirow[t]{2}{*}{$\begin{array}{l}\text { "K10: } \\
\text { getirir." }\end{array}$} & Sorumluluklarını & yerine & $\begin{array}{l}\text { "K10. G1: Sorumluluk almaya } \\
\text { istekli olduğunu gösterir." }\end{array}$ \\
\hline & & & $\begin{array}{l}\text { "K10. G2: Üstlendiğ } \mathrm{i} \\
\text { sorumluluğu yerine getirir." }\end{array}$ \\
\hline
\end{tabular}

"Anne ben de bir köpek sahibi olmak istiyorum." "Ben hem beslerim hem de dolaştırırım"

"Ege ile İnci küçük mavi çadırı kurmaya çalıştılar. Ancak direkler bir türlü yerinde durmuyordu. Biraz uğraştıktan sonra direkleri dikip kazıkları çakmayı başardılar. Sonunda çadır kurulmuştu."

"K10. G3: Sorumluluklar yerine getirilmediğinde olası sonuçları söyler."

\begin{tabular}{|c|c|c|}
\hline \multirow{3}{*}{$\begin{array}{l}\text { "K11: Atatürk ile ilgili etkinliklerde } \\
\text { sorumluluk alır." }\end{array}$} & soyich. & \multirow{3}{*}{ Gözlenmedi } \\
\hline & $\begin{array}{l}\text { "K11. G1: Atatürk ile ilgili } \\
\text { etkinliklere kat1lır." }\end{array}$ & \\
\hline & $\begin{array}{l}\text { "K11. G2: Atatürk ile ilgili duygu } \\
\text { ve düşüncelerini farklı } \\
\text { etkinliklerle ifade eder." }\end{array}$ & \\
\hline $\begin{array}{l}\text { "K12: Değişik ortamlardaki kurallara } \\
\text { uyar." }\end{array}$ & $\begin{array}{l}\text { "K12. G1: Değişik ortamlardaki } \\
\text { kuralların belirlenmesinde } \\
\text { düşüncesini söyler." }\end{array}$ & Gözlenmedi \\
\hline
\end{tabular}

"İnsanlar mangal yaptıktan sonra ateşi söndürmemişler ve yangının başlamasına sebep olmuşlardı." 
5-6 Yaş Resimli Çocuk Kitaplarındaki Resim ve İçerik Ögelerinin MEB Okul Öncesi Eğitim Programı SosyalDuygusal Alan Kazanım ve Göstergeler Açısından İncelenmesi

Analysis of the Picture and Content Items of the Children's Picture Book for 5-6 Years Old in terms of SocialEmotional Field Outcomes and Indicators in MEB Preschool Education Program

"K12. G2: Kuralların gerekli olduğunu söyler.”

"K12. G3: İstekleri ile kurallar çeliştiğinde kurallara uygun davranır."

"K12. G4: Nezaket kurallarına uyar."

"K13: Estetik değerleri korur.”

"K13. G1: Çevresinde gördüğü güzel ve rahatsız edici durumları söyler."

"K13. G2: Çevresini farklı biçimlerde düzenler."

"K13. G3: Çevredeki güzelliklere değer verir."

\begin{tabular}{ll}
\hline $\begin{array}{l}\text { "K14: Sanat eserlerinin değerini fark } \\
\text { eder." }\end{array}$ & $\begin{array}{l}\text { "K14. G1: Sanat eserlerinde } \\
\text { gördüklerini ve işittiklerini } \\
\text { söyler." } \\
\text { "K14. G2: Sanat eseri ile ilgili } \\
\text { duygularını açılar." } \\
\\
\text { "K14. G3: Sanat eserlerinin } \\
\text { korunmasina özen gösterir." }\end{array}$ \\
\hline "K15. G1: Kendine ait beğendiği \\
ve beğenmediği özellikleri \\
söyler."
\end{tabular}

"K15. G2: Grup önünde kendini ifade eder."

"K15. G3: Gerektiği durumlarda farklı görüşlerini söyler."

"K15. G4: Gerektiğinde liderliği üstlenir."
"Tanımadığımız insanlarla bir yere gitmememiz gerekiyor." diye anlatt1 kardeşine. "Yabancılara her zaman hayır demeliyiz."

"Çok zevkli bir oyundur. Ebe olmayı kabul edersen hep birlikte oynayabiliriz." Ebe olma fikri Makas'ın hiç hoşuna gitmedi ama oyunu da merak ediyordu. Bir kumaş parçasıyla Makas'ın gözlerini bağladılar."

"Sofrayı ne kadar güzel hazırlamıştı annesi. "Ellerine sağlık canım annem her şey çok harikaydı."

"Manzara o kadar güzeldi ki! Mis gibi deniz kokan hava, göz alabildiğine uzanan mavilik, ufukta küçük balıkçı tekneleri göze çarpıyordu."

"Pet şişe, plastik terlik, yiyecek içecek kapları ve daha birçok pisliğin bulunduğu bir yere geldiler. Derya kendi attığı gofret kabını ve gazoz şişesini görünce kendinden utand1. Meğer ne kadar kötülük ediyorlardı deniz halkına."

"Tarım makineleri toprağı kazıp, bu yılın bitkileri için hazırladı. Tohumlar ekildi, filizlendi."

"Etrafimızdaki insanları temiz olmaları için uyaralım. Bundan böyle tam bir 'Temiz çevre savaşçısı' olmaya karar vermişlerdi."

Gözlenmedi

"Şimdi oldu mu? Benim resmimi beğendin mi?" diye sordu küçük kız. "Senin resmini çok beğendim." dedi Ay çocuğu.

Gözlenmedi

"Lak Lak Bey’in memnuniyetsizliği hiç bitmezdi ki!

"Zaten şu uzun bacaklarıma da sinir oluyorum. Koşarken birbirlerine dolaşıyorlar."

"Kekito sahneye çıkarken iki haftadır nasıl çalıştığını düşündü. Heyecanını bastırmayı başardı ve özenle yazdığı şiirini yüksek sesle ve tane tane ve yürekten okumaya başladı."

"Babacığım baksana hava berbat! Biliyorsun Beyaz Papatya ile buluşmak için sözleşmiştik ama herhalde bu yağmurda o da gelmez. Gitmesem mi acaba diye düşünüyorum." dedi.

"Derhal yardım etmesi gerekiyordu ancak büyük yağmur bulutları çok uzak bir şehre, yağmur yağdırmaya gitmişlerdi. Onlar gelene kadar yangını durdurması gerekiyordu ama nasıl? Bulutçuk hiç düşünmeden doğruca ormana gitti. Korkmasına rağmen olanca gücüyle yağmur yağdırmaya başladı. Bu sırada işlerini bitiren büyük bulutlar Pembe Bulut'a yardıma geldiler." 


\begin{tabular}{ll}
\hline "K16: Toplumsal yaşamda bireylerin & "K16. G1: Toplumda farklı rol ve \\
farklı rol ve görevleri olduğunu & görevlere sahip kişiler olduğunu \\
açılar." & söyler."
\end{tabular}
açıklar."
“Furkan'ın ailesi polise haber verdi. Polisler ailesinden Furkan'ın üstündeki klyafetleri tarif etmesini istedi. Ayrıca Furkan'ın fotoğrafını aldılar. Gerekirse üzerinde 'Aranıyor' yazan afişler yapılacakmış."
"K16. G2: Aynı kişinin farklı rol ve görevleri olduğunu söyler."

\begin{tabular}{llll}
\hline "K17: & Başkalarıla & sorunlarını "K17. G1: Başkaları ile \\
& & $\begin{array}{l}\text { "Korunlarını onlarla konuşarak } \\
\text { çözer." }\end{array}$
\end{tabular}

"K17. G2: Arkadaşlarıyla sorunlarını çözemediği zamanlarda yetişkinlerden yardım ister."

"K17. G3: Gerekli zamanlarda uzlaşmacı davranır."
Gözlenmedi

"Korkunç geçen yemekten sonra annem ve babam tekrar benimle konuşmak istediler. Bana bu durumun benim suçum olmadığını tekrarladılar. Sonra benim onları barıştıramayacağımı, ayrı olmanın onları daha mutlu ettiğini anlattılar. Annem ve babam olmaya devam edeceklerdi. Onlar mutlu olunca ben de mutlu olacaktım. Biz bir aileydik. Ayrı evlerde oturmamız bunu değiştirmeyecekti. Bana söz verdiler."

"Anneme Kerem'in yaptıklarının hepsini anlattım. Annem "Niçin bize söylemedin?" dedi. Beni suçlu bulacaklarından ve Kerem'i şikâyet ettiğim için daha çok kızıp yapacaklarından korktuğumu anlattım. Annem "Öyle şey olur mu? Her zaman bizimle konuşman gerekir. Eğer hatalıysan biz sana söyleriz. Zarar gördüğünde ise seni koruruz." dedi. Cok rahatladım."

"Çocuklar Mihrişah Sultan'a kızgındılar ancak büyükleri hep 'Affetmek büyüklüktendir.' derlerdi. Mihrişah Sultan çocuklardan özür diledi. Çocuklar yeni arkadaşlarına oyunlarında bir rol verdiler."

Tablo 2 incelendiğinde resimli çocuk kitaplarının içerik ögelerinde yer alan her göstergeye ait örnek cümleler görülmektedir. $\mathrm{Bu}$ verilere bakıldığında resimli çocuk kitaplarının içerik ögelerinde sosyal-duygusal alan kazanım ve göstergelerinin hepsine yer verilmediği gözlenmektedir.

\section{Tartışma}

Çalışma sonuçları değerlendirildiğinde (K1) "Kendisine ait özellikleri tanıtır." kazanımına ait dört gösterge incelendiğinde resimli çocuk kitaplarının içerik ögelerinde (K1G4) "Duyuşsal özelliklerini söyler.” göstergesine ilk sırada yer verildiği görülmektedir. Resim ögelerinde de (K1G4) "Duyuşsal özelliklerini söyler." göstergesine ilk sırada yer verildiği görülmektedir. (K1G4) "Duyuşsal özelliklerini söyler." göstergesinin incelenen resimli çocuk kitaplarında resim ve içerik ögeleri açısından en çok bulunan gösterge olduğu söylenebilir. (K1G2) "Yaşını söyler" göstergesine ise çocuk kitaplarının hem içerik hem de resim ögeleri arasında hiç yer verilmediği dikkati çekmektedir. (K1G1) "Adını/soyadını söyler." ve (K1G3) "Fiziksel özelliklerini söyler.” göstergelerine hem içerik hem de resim ögeleri arasında yer verilmiştir. Resimli çocuk kitaplarının resim ve içerik ögeleri incelendiğinde özellikle duyuşsal özelliklerin belirgin bir şekilde yansıtıldı̆̆ı söylenebilir. Ancak ad/soyad, fiziksel özellikler gibi ifadeler yetersiz bir şekilde yansıtılmaktadır. Yaş ifadesine ise hem içerik hem de resim ögelerinde yer verilmemiştir. Yapılan çalışmada (K1G4) "Duyuşsal özelliklerini söyler.” göstergesinin tüm göstergeler içerisinde en yüksek orana sahip olduğu görülmektedir. Sildir ve Tüfekci Akcan (2018) tarafindan 3-6 yaş çocuklara eğitim veren okullarda bulunan 300 adet resimli hikâye kitabı, sosyal-duygusal alandaki kazanımları desteklemeleri açısından incelenmiştir. Yapılan 
5-6 Yaş Resimli Çocuk Kitaplarındaki Resim ve İçerik Ögelerinin MEB Okul Öncesi Eğitim Programı SosyalDuygusal Alan Kazanım ve Göstergeler Açısından İncelenmesi

Analysis of the Picture and Content Items of the Children's Picture Book for 5-6 Years Old in terms of SocialEmotional Field Outcomes and Indicators in MEB Preschool Education Program

araştırmada, sosyal-duygusal alanda bulunan bütün göstergeler içerisinde (K1G4) "Duyuşsal özelliklerini söyler." göstergesinin en yüksek orana sahip olduğu sonucuna ulaşılmıştır. Bu sonuçlar, erken çocukluk dönemine ait öykü kitaplarının duyuşsal özellikler konusunda yeterince veri barındırdığını ortaya koymaktadır.

(K2) “Ailesiyle ilgili özellikleri tanıtır” kazanımına ait beş gösterge incelendiğinde resimli çocuk kitaplarının içerik ögelerinde (K2G1) "Anne/babasının adını, soyadını, mesleğini vb. söyler.", (K2G4) "Telefon numarasını söyler." ve (K2G5) "Evinin adresini söyler." göstergelerine yer verilmiştir. Bunun yanında (K2G2) "Anne/babasının saç rengi, boyu, göz rengi gibi fiziksel özelliklerini söyler” ve (K2G3) “Teyze/amca gibi yakın akrabalarının isimlerini söyler." göstergelerine resimli çocuk kitaplarının içerik ögelerinde hiç yer verilmediği görülmektedir. Resim ögelerinde ise (K2) "Ailesiyle ilgili özellikleri tanıtır" kazanımına hiç yer verilmemiştir. (K2G1) "Anne/babasının adını, soyadını, mesleğini vb. söyler.", (K2G4) "Telefon numarasını söyler." ve (K2G5) "Evinin adresini söyler." göstergelerine içerik ögelerinde yer verilmelerine rağmen resim ögelerinde hiç yer verilmemesi dikkat çekmektedir. Kılınçcı ve Can (2020), Uşak İl Halk Kütüphanesinde bulunan ve son 1 yılda en çok talep gören 56 adet 3-6 yaş arası resimli çocuk kitaplarını incelemişlerdir. Araştırmada resimli çocuk kitapları sosyal-duygusal beceriler açısından değerlendirilmiştir. Sosyal-duygusal alandaki (K2) "Ailesiyle ilgili özellikleri tanıtır." kazanımının incelenen kitaplarda oldukça az görüldüğü tespit edilmiştir. Yapılan çalışmada da resimli çocuk kitaplarının içerik ögelerinde (K2) “Ailesiyle ilgili özellikleri tanıtır.” kazanımına düşük düzeyde yer verildiği görülmüştür ve bahsedilen araştırma ile paralellik gösterdiği söylenebilir. Resim ögelerinde ise (K2) “Ailesiyle ilgili özellikleri tanıtır.” kazanımına hiç yer verilmemiştir. (K2) "Ailesiyle ilgili özellikleri tanıtır." kazanımına bulunan göstergelerin sözel ifadelere dayalı olması sebebiyle çocuk kitaplarının resim ögelerine yansıtılmasında yetersiz kaldığ düşünülmektedir.

(K3) "Kendini yaratıcı yollarla ifade eder." kazanımına ait üç gösterge incelendiğinde resimli çocuk kitaplarının hem içerik hem de resim ögelerinde (K3G1) "Duygu, düşünce ve hayallerini özgün yollarla ifade eder.”, (K3G2) "Nesneleri alışılmışın dışında kullanır." ve (K3G3) "Özgün özellikler taşıyan ürünler oluşturur." göstergelerine yer verilmiştir. Okul öncesi dönemde bulunan çocukların problem çözme becerileri ve yaratıcılıkları etkileşimli kitap okuma aracılığıyla geliştiği bilinmektedir. Bunun yanında kitaplar, çocukların nedensonuç ilişkisi kurarak analitik düşünmelerine olanak sağlamaktadır (Bennett, Weigel ve Martin, 2002; Aram ve Levin, 2002; Tür ve Turla, 1999). Bu düşünceler doğrultusunda erken çocukluk yaratıcılığın en yoğun olduğu dönemlerden biri olduğu için resimli çocuk kitaplarının yaratıcılığı destekleyecek nitelikte resim ve içerik ögeleri ile desteklenmesi gerektiği açıktır.

(K4) "Bir olay ya da durumla ilgili olarak başkalarının duygularını açıklar." kazanımına içerik ögelerindeki tüm kazanımlar arasında ilk sırada yer verilmiştir. (K4) "Bir olay ya da durumla ilgili olarak başkalarının duygularını açıklar.” kazanımına ait üç gösterge incelendiğinde (K4G1) "Başkalarının duygularını söyler.", (K4G2) "Başkalarının duygularının nedenlerini söyler.”, (K4G3) "Başkalarının duygularının sonuçlarını söyler.” göstergelerine resimli çocuk kitaplarının içerik ögelerinde yer verilmiştir. Resim ögelerinde de (K4G1) "Başkalarının duygularının söyler.", (K4G2) "Başkalarının duygularının nedenlerini söyler." 
ve (K4G3) "Başkalarının duygularının sonuçlarını söyler." göstergelerine yer verilmiştir. Kızıltaş, Ertör ve Karademir (2018) tarafından hazırlanan etkinlik planlarına yönelik yapılan bir araştırmada da en yüksek düzeyde yer verilen kazanımlardan bir tanesinin "Bir olay ya da durumla ilgili olarak başkalarının duygularını açıklar." kazanımı olduğu belirlenmiştir. Yapılan bu çalışmada da (K4) "Bir olay ya da durumla ilgili olarak başkalarının duygularını açıklar." kazanımına en yüksek düzeyde yer verildiği için Kızıltaş, Ertör ve Karademir'in (2018) araştırması ile paralellik gösterdiği söylenebilir.

(K5) "Bir olay ya da durumla ilgili olumlu/olumsuz duygularını uygun yollarla gösterir." kazanımına ait iki gösterge incelendiğinde (K5G1) "Olumlu/olumsuz duygularını sözel ifadeler kullanarak açıklar." ve (K5G2) "Olumsuz duygularını olumlu davranışlarla gösterir." göstergelerine resimli çocuk kitaplarının içerik ögelerinde yer verilmiştir. Bu araştırmada (K5) "Bir olay ya da durumla ilgili olumlu/olumsuz duygularını uygun yollarla gösterir." kazanımına üst sıralarda yer verilirken, Kılınçcı ve Can (2020) tarafından yapılan başka bir araştırmada da bu kazanım en yüksek düzeyde yer verilen kazanım olarak belirlenmiştir. Resim ögelerinde ise (K5G1) “Olumlu/olumsuz duygularını sözel ifadeler kullanarak açıklar.” ve (K5G2) "Olumsuz duygularını olumlu davranışlarla gösterir.” göstergelerine yer verilmiştir. Saarni (1999) çocukların sosyal becerilerinin gelişmesinde duygularını bilme, duygularını doğru bir şekilde ifade etmeyi kazanılması gereken beceriler arasında yer aldığını belirtmektedir. Garner ve Spears'e (2000) göre ise (K5G1) "Olumlu/olumsuz duygularını olumlu sözel ifadeler kullanarak açıklar." göstergesinde olduğu gibi çocukların olumlu veya olumsuz duygularını yerinde ve doğru bir şekilde ifade edebiliyor olması akademik ve sosyal-duygusal alanlardaki başarılarını da olumlu yönde etkilemektedir. Yapılan çalışmada da (K5G1) "Olumlu/olumsuz duygularını sözel ifadeler kullanarak açıklar.” göstergesine yüksek düzeyde yer verilmiş olması bu görüşü destekler niteliktedir.

(K6) "Kendisinin ve başkalarının haklarını korur." kazanımına ait dört gösterge incelendiğinde (K6G1) "Haklarını söyler.”, (K6G2) "Başkalarının hakları olduğunu söyler.”, (K6G3) "Haksızlığa uğradığında tepki verir.” ve (K6G4) "Başkalarına haksızlık yapıldığında tepki verir." göstergelerine resimli çocuk kitaplarının içerik ögelerinde yer verilmiştir. Resim ögelerinde ise (K6) "Kendisinin ve başkalarının haklarını korur." kazanımının (K6G2) "Başkalarının hakları olduğunu söyler.", (K6G3) "Haksızlığa uğradığında tepki verir." ve (K6G4) "Başkalarına haksızlık yapıldığında tepki verir." göstergelerine yer verilmiştir. Bunun yanında (K6G1) "Haklarını söyler." göstergesine resimli çocuk kitaplarının resim ögelerinde hiç yer verilmediği görülmektedir. (K6G1) "Haklarını söyler.” göstergesine içerik ögelerinde yer verilmesine rağmen resim ögelerinde yer verilmediği dikkat çekmektedir. Sildir (2016) tarafından, okul öncesi için yazılan eserlerinin, MEB 2013 Programı'nda bulunan sosyalduygusal alandaki kazanımları desteklemeleri açısından bir araştırma yapılmıştır. Araştırmada 300 kitap incelenmiş ve (K6) "Kendisinin ve başkalarının haklarını korur." kazanımının son sıralarda yer aldığı sonucuna ulaşılmıştır. Yapılan çalışmada da bahsedilen kazanıma düşük düzeyde yer verildiği gözlendiği için araştırmaların paralellik gösterdiği söylenebilir. İş (2017) tarafından da okul öncesi programındaki kazanımları, sınıf ve okul öncesi branşlarındaki öğretmenlerin gerçekleştirilip gerçekleştirilmediğine dair başka bir araştırma yapılmıştır. Okul öncesi dönem öğretmenlerinin uyguladıkları eğitim programında, çocuk hakları konusunu içinde barındıran sosyal-duygusal gelişim alanı kazanımları ve kazanımları çocuklara 
5-6 Yaş Resimli Çocuk Kitaplarındaki Resim ve İçerik Ögelerinin MEB Okul Öncesi Eğitim Programı SosyalDuygusal Alan Kazanım ve Göstergeler Açısından İncelenmesi

Analysis of the Picture and Content Items of the Children's Picture Book for 5-6 Years Old in terms of SocialEmotional Field Outcomes and Indicators in MEB Preschool Education Program

kazandıracak etkinlikleri yeterli gördükleri ve çocuk hakları konusuna yönelik kazanımları gerçekleştirebilmek amacıyla öğrencilere değişik etkinliklerle birlikte uygulamalar gerçekleştirdikleri sonucu elde edilmiştir. Yapılan çalışmada ise bahsedilen (K6) "Kendisinin ve başkalarının haklarını korur." kazanımına içerik ögelerinde yer verildiği ancak kazanımın (K6G1) "Haklarını söyler." göstergesine resim ögelerinde hiç yer verilmediği incelenen araştırma ile ters düşmektedir. Bu doğrultuda (K6) "Kendisinin ve başkalarının haklarını korur." kazanımının çocuklar tarafından benimsenmesini sağlayacak nitelikli kitapların ve çocukların davranışlarında somut olarak gözlenebilmesi için etkinlik ve uygulamalara yer verilmesinin olumlu sonuçlar doğurabileceği düşünülmektedir.

(K7) "Bir işi ya da görevi başarmak için kendini güdüler." kazanımına ait iki gösterge incelendiğinde (K7G1) "Yetişkin yönlendirmesi olmadan bir işe başlar." ve (K7G2) "Başladığı işi zamanında bitirmek için çaba gösterir." göstergelerine resimli çocuk kitaplarının içerik ögelerinde yer verilmiştir. Resim ögelerinde de (K7G1) "Yetişkin yönlendirmesi olmadan bir işe başlar.", (K7G2) "Başladığı işi zamanında bitirmek için çaba gösterir." göstergelerine yer verilmiştir. İbiş (2017) tarafından yapılan bir araştırmada 5-6 yaş çocuklarına içerisinde görevleri tamamlama, kendini kontrol etme gibi sosyal becerilerin de yer aldığı bir yaratıcı drama programı uygulanmıştır. $\mathrm{Bu}$ araştırmanın sonucunda uygulanan program doğrultusunda görevleri tamamlama, kendini kontrol etme gibi sosyal becerilerin gelişiminde ilerleme olduğu görülmüştür. Okul öncesi dönem çocuklarında önemli bir yere sahip olan resimli çocuk kitaplarında da çocukların başladıkları görevleri yerine getirmelerini destekleyecek nitelikte görsel ve içerik ögelere yer verilmesi büyük önem taşımaktadır.

(K8) "Farklı1ıklara saygı gösterir." kazanımına ait üç gösterge incelendiğinde (K8G1) "Kendisinin farklı özellikleri olduğunu söyler.”, (K8G2) "İnsanların farklı özellikleri olduğunu söyler." ve (K8G3) "Etkinliklerde farklı özellikteki çocuklarla birlikte yer alır." göstergelerine resimli çocuk kitaplarının içerik ögelerinde yer verilmiş̧ir. Resim ögelerinde de (K8G1) “Kendisinin farklı özellikleri olduğunu söyler.”, (K8G2) “İnsanların farklı özellikleri olduğunu söyler." ve (K8G3) "Etkinliklerde farklı özellikteki çocuklarla birlikte yer alır." göstergelerine yer verilmiştir. Leming (2000) karakter eğitimi üzerine yaptığı bir araştırmasında çeşitli kökenlerden gelen çocukların bulunduğu bir gruba yedi temel değer ögesini (sevgi, saygl, adalet, dürüstlük vb.) bünyesinde barındıran kitaplar okumuştur. Araştırmanın sonucunda da okunan kitapların çocukların bu alana yönelik algılarını olumlu yönde geliştirdiği sonucuna ulaşmıştır. Bu araştırmadan yola çıkarak resimli çocuk kitaplarında çeşitli değer ögelerine daha çok yer verilmesi gerektiği düşünülmektedir.

(K9) "Farklı kültürel özellikleri açıklar." kazanımına ait üç gösterge incelendiğinde (K9G3) "Farklı ülkelerin kendine özgü kültürel özellikleri olduğunu söyler." göstergesine resimli çocuk kitaplarının içerik ögelerinde yer verilmiştir. Bunun yanında (K9G1) "Kendi ülkesinin kültürüne ait özellikleri söyler." ve (K9G2) "Kendi ülkesinin kültürü ile diğer kültürlerin benzer ve farklı özelliklerini söyler." göstergelerine resimli çocuk kitaplarının içerik ögelerinde hiç yer verilmediği görülmektedir. Resim ögelerinde ise (K9) "Farklı kültürel özellikleri açıklar." kazanımına hiç yer verilmemiştir. (K9G3) "Farklı ülkelerin kendine özgü kültürel özellikleri olduğunu söyler." göstergesine içerik ögelerinde yer verilmesine rağmen resim ögelerinde hiç yer verilmemesi dikkat çekmektedir. Çocuklar için hazırlanan resimli 
çocuk kitaplarının onların kültür hakkında farkındalık kazanmalarını, kendi kültürleriyle birlikte farklı kültürler hakkında da gereken bilgileri edinebilmelerini sağlayacak nitelikte olmaları gerekmektedir (Mendoza ve Reese, 2001). Yapılan çalışmanın sonucunda incelenen kitapların istenileni vermede yeterli olmadığı görülmektedir. Bu açıdan çocuk kitaplarında kültürel değerleri kazandırmayı destekleyecek nitelikte resim ve içerik ögeleri olmasına özen gösterilebilir.

(K10) "Sorumluluklarını yerine getirir." kazanımına ait üç gösterge incelendiğinde (K10G1) "Sorumluluk almaya istekli olduğunu gösterir.", (K10G2) "Üstlendiği sorumluluğu yerine getirir." ve (K10G3) "Sorumluluklar yerine getirilmediğinde olası sonuçları söyler." göstergelerine resimli çocuk kitaplarının içerik ögelerinde yer verilmiştir. Resim ögelerinde ise (K10G1) "Sorumluluk almaya istekli olduğunu gösterir.", (K10G2) "Üstlendiği sorumluluğu yerine getirir." göstergelerine yer verilmiştir. Bunun yanında (K10G3) "Sorumluluklar yerine getirilmediğinde olası sonuçları söyler." göstergesine resimli çocuk kitaplarının resim ögelerinde hiç yer verilmediği görülmektedir. Kılınçcı ve Can (2020) tarafından yapılan araştırmada (K10) “Sorumluluklarını yerine getirir.” kazanımının resimli çocuk kitaplarında ele alınması bakımından ikinci sırada yer aldığı görülmüştür. Yapılan çalışmada da (K10) "Sorumluluklarını yerine getirir." kazanımına yer verilme sırasına bakıldığında üst sıralarda yer verildiği için araştırmaların paralellik gösterdiği söylenebilir. Gönen, Katrancı, Uygun ve Uçuş (2011) tarafından yapılan başka bir araştırmada ise incelenen kitaplarda en az düzeyde yer verilmiş değerlerden birinin sorumluluk olduğu sonucuna ulaşılmıştır. $\mathrm{Bu}$ araştırmada sorumluluk kavramına yer verilme düzeyinin çok düşük olması yapılan çalışmadan elde edilen sonuç ile ters düşmektedir.

(K11) “Atatürk ile ilgili etkinliklerde sorumluluk alır." kazanımına resimli çocuk kitaplarının hem içerik hem de resim ögelerinde yer verilmemiştir. Yapılan araştırmalara bakıldığında bu kazanımın yer aldığı kitapların çok az sayıda olduğu ve niteliksel açıdan iyi düzeyde olan yetersiz sayıda kitap olduğu saptanmıştır (Veziroğlu, 2009). Sapsağlam (2020) tarafından yapılan bir araştırmada Okul Öncesi Eğitim Programları kapsamında yer verilen milli kahramanları incelemek amaçlanmıştır. Araştırma sonucunda, 2013 Okul Öncesi Eğitim Programı incelendiğinde milli kahramanlar içerisinde sadece Atatürk'e yer verildiği sonucuna ulaşılmıştır. Ancak yapılan çalışmada incelenen resimli çocuk kitaplarında Atatürk ile ilgili hiçbir bilgi ve özelliğe yer verilmediği görülmektedir. İki çalışma da Atatürk’e yönelik yazılan resimli çocuk kitaplarının sayısının arttırılmasını ve Okul Öncesi Eğitim Programlarında milli kahramanlar içerisinde Atatürk gibi birçok kahramanın da ele alınması gerektiğinin önemli olduğu sonucunu destekler niteliktedir. Çocukların okul öncesi dönemde özellikle hedeflenen bu kazanım hakkında bir bilince sahip olması gerekirken bu kazanıma yeterli düzeyde önem gösterilmemesi üzerinde düşünülmesi gereken önemli bir durumdur.

(K12) “Değişik ortamlardaki kurallara uyar.” kazanımına ait dört gösterge incelendiğinde (K12G2) "Kuralların gerekli olduğunu söyler.”, (K12G3) "İstekleri ile kurallar çeliştiğinde kurallara uygun davranır." ve (K12G4) "Nezaket kurallarına uyar." göstergelerine resimli çocuk kitaplarının içerik ögelerinde yer verilmiştir. Bunun yanında (K12G1) "Değişik ortamlardaki kuralların belirlenmesinde düşüncesini söyler.” göstergesine resimli çocuk kitaplarının içerik ögelerinde hiç yer verilmediği görülmektedir. Resim ögelerinde ise (K12G1) "Değişik ortamlardaki kuralların belirlenmesinde düşüncesini söyler." , (K12G2) "Kuralların 
5-6 Yaş Resimli Çocuk Kitaplarındaki Resim ve İçerik Ögelerinin MEB Okul Öncesi Eğitim Programı SosyalDuygusal Alan Kazanım ve Göstergeler Açısından İncelenmesi

Analysis of the Picture and Content Items of the Children's Picture Book for 5-6 Years Old in terms of SocialEmotional Field Outcomes and Indicators in MEB Preschool Education Program

gerekli olduğunu söyler.” ve (K12G4) "Nezaket kurallarına uyar.” göstergelerine yer verilmiştir. Bunun yanında (K12G3) "İstekleri ile kurallar çeliştiğinde kurallara uygun davranır." göstergesine resimli çocuk kitaplarının resim ögelerinde hiç yer verilmediği görülmektedir. Court ve Rosental (2007) tarafından yapılan araştırmada İsrail'de kurallara uyma ile ilgili olan değere resimli çocuk kitaplarında ne kadar yer verildiğini incelenmiştir. Bu araştırmanın sonucunda bu değere diğerlerine göre en az düzeyde yer verildiği ortaya çıkmıştır. Yapılan çalışmada ise (K12) "Değişik ortamlardaki kurallara uyar." kazanımına düşük düzeyde yer verilmediği görülmüştür. $\mathrm{Bu}$ açıdan araştırma sonuçlarının farklılık gösterdiği düşünülmektedir. Evrensel bir değer olan kurallara uymaya yönelik yapılan çalışmaların tüm dünyada desteklenmesinin çocukların gelişimini olumlu yönde etkileyeceği söylenebilir.

(K13) "Estetik değerleri korur." kazanımına ait üç gösterge incelendiğinde (K13G1) "Çevresinde gördüğü güzel ve rahatsız edici durumları söyler.", (K13G2) "Çevresini farklı biçimlerde düzenler." ve (K13G3) "Çevredeki güzelliklere değer verir.” göstergelerine resimli çocuk kitaplarının içerik ögelerinde yer verilmiştir. Resim ögelerinde de (K13G1) "Çevresinde gördüğü güzel ve rahatsız edici durumları söyler.", (K13G2) "Çevresini farklı biçimlerde düzenler." ve (K13G3) "Çevredeki güzelliklere değer verir.” göstergelerine yer verilmiştir. Çocukta estetik değerlerin gelişimi sosyal-duygusal alan açısından büyük bir öneme sahiptir (Fox ve Schirrmacher, 2014). Dirican ve Dağlığlu (2014) tarafından yapılan araştırmada 3-6 yaşa yönelik 135 adet resimli hikâye kitabı bazı değerler açısından incelenmiştir. Yapılan araştırmada estetik değerine orta derecede yer verildiği görülmektedir. Ayrıca estetik değerlere, incelenen kitaplarda "güzel, süslenmek ve beğenmek" şeklinde yer verildiği tespit edilmiştir. Okul öncesi dönem çocuklarında estetik algı yaratmak için bu değerlere resimli çocuk kitaplarında yer verilmesinin üzerinde önemle durulması gereken bir konu olduğu düşünülmektedir. Böylece çocuklarda estetik farkındalığın kazandırılması desteklenebilir.

(K14) "Sanat eserlerinin değerini fark eder." kazanımına ait üç gösterge incelendiğinde (K14G1) "Sanat eserlerinde gördüklerini ve işittiklerini söyler." ve (K14G2) "Sanat eseri ile ilgili duygularını açıklar." göstergelerine resimli çocuk kitaplarının içerik ögelerinde yer verilmiştir. Bunun yanında (K14G3) "Sanat eserlerinin korunmasına özen gösterir." göstergesine hiç yer verilmediği görülmektedir. Resim ögelerinde ise (K14G1) "Sanat eserlerinde gördüklerini ve işittiklerini söyler.", (K14G2) "Sanat eseri ile ilgili duygularını açıklar." ve (K14G3) "Sanat eserlerinin korunmasına özen gösterir.” göstergelerine yer verilmiştir. (K14G3) "Sanat eserlerinin korunmasına özen gösterir." göstergesine resim ögelerinde yer verilirken içerik ögelerinde yer verilmemesi dikkat çekmektedir. (K14) "Sanat eserlerinin değerini fark eder." kazanımının resim ve içerik ögelerinde bulunma oranının düşüklüğü bu kazanımın çocuklara verilmesinde kitapların yetersiz kaldığının bir göstergesidir. Benić, Herzog ve Sušić (2017), ilkokul-okul öncesi dönem eğitimcilerinin yaratıcılık ve sanat konularının gerekliliği hakkındaki tutum ve görüşlerinin erken çocuklukta aldıkları eğitimöğretimin kalitesinden kaynaklanabileceğini savunmuşlardır.

(K15) "Kendine güvenir." kazanımına ait dört gösterge incelendiğinde (K15G1) "Kendine ait beğendiği ve beğenmediği özellikleri söyler.", (K15G2) "Grup önünde kendini ifade eder.", (K15G3) "Gerektiği durumlarda farklı görüşlerini söyler.” ve (K15G4) "Gerektiğinde liderliği üstlenir.” göstergelerine resimli çocuk kitaplarının içerik ögelerinde yer 
verilmiştir. Resim ögelerinde ise (K15G2) "Grup önünde kendini ifade eder.”, (K15G3) "Gerektiği durumlarda farklı görüşlerini söyler.” ve (K15G4) "Gerektiğinde liderliği üstlenir." göstergelerine yer verilmiştir. Bunun yanında (K15G1) "Kendine ait beğendiği ve beğenmediği özellikleri söyler.” göstergesine içerik ögelerinde hiç yer verilmemiştir. (K15G1) "Kendine ait beğendiği ve beğenmediği özellikleri söyler.” göstergesine içerik ögelerinde yer verilmesine rağmen resim ögelerinde hiç yer verilmediği dikkat çekmektedir. Tanju (2010) tarafından yapılan bir araştırmada 3-6 yaş dönemine yönelik hazırlanan çocuk kitaplarında çocukların hikâye kahramanlarının yerine kendilerini koydukları için kahraman ve konuların çocukların günlük yaşamlarında deneyimledikleri durum ve olaylardan elde edilmesine özen gösterilmesi, bu yaş grubundaki çocuklar için hazırlanan kitapların güven, sevgi ve başarı duygularını desteklemesi gerektiğini belirtilmektedir. Yapılan bu araştırma da çocuk kitaplarında (K15) "Kendine güvenir." kazanımına yer vermenin önemine bir kez daha dikkat çekmektedir. Kendine güven duygusunun gelişmesi ve gerçekleşmesi için okul öncesi dönem yaşlarının öneme sahip olduğu düşünülmektedir. Kitaplar ve çeşitli etkinlikler yoluyla güven duygusu kazandırılabilir.

(K16) "Toplumsal yaşamda bireylerin farklı rol ve görevleri olduğunu açıklar." kazanımına ait iki gösterge incelendiğinde (K16G1) "Toplumda farklı rol ve görevlere sahip kişiler olduğunu söyler.” göstergesine resimli çocuk kitaplarının içerik ögelerinde yer verilmiştir. Bunun yanında (K16G2) "Aynı kişinin farklı rol ve görevleri olduğunu söyler." göstergesine hiç yer verilmediği görülmektedir. Resim ögelerinde de (K16G1) "Toplumda farklı rol ve görevlere sahip kişiler olduğunu söyler.” göstergesi yer alırken (K16G2) "Aynı kişinin farklı rol ve görevleri olduğunu söyler.” göstergesine resimli çocuk kitaplarının resim ögelerinde hiç yer verilmediği dikkat çekmektedir.

Her birey, dünyaya geldiği andan itibaren sosyalleşir ve toplumun bir üyesi olarak kabul edilir. Sosyalleşme sürecinde çocukların nitelikli bir sosyo-kültürel ortamda yetişmesi, benliklerini olumlu yönde etkilemektedir (Kağıtçıbaşı, 2007). Okul öncesi dönemin çocukların çevresinde bulunan kişilerle özdeşim kurarak toplumda yer alan farklı rolleri içselleştirmesi açısından kritik bir öneme sahip olduğu düşünülmektedir. Sildir ve Tüfekci Akcan (2018) ve Kılınçcı ve Can'ın (2020) yaptıkları araştırmalarda (K16) “Toplumsal yaşamda bireylerin farklı rol ve görevleri olduğunu açıklar.” kazanımına çocuk kitaplarında en düşük düzeyde yer verildiği tespit edilmiştir. Yapılan çalışmada da en az yer verilen kazanımlardan biri olduğu görülmektedir. Yapılan üç çalışmanın (K16) "Toplumsal yaşamda bireylerin farklı rol ve görevleri olduğunu açıklar.” kazanımını açısından paralellik gösterdiği söylenebilir. Resimli çocuk kitapları incelendiğinde bu kazanımın çocuklara aktarılmasında yetersiz kaldığı görülmektedir. Okul öncesi dönemde çocukların toplumsal yaşamdaki rol ve görevlere ilişkin farkındalığının resimli çocuk kitapları aracılığıyla etkili bir şekilde aktarılabileceği düşünülmektedir.

(K17) "Başkalarıyla sorunlarını çözer." kazanımına ait üç gösterge incelendiğinde (K17G1) "Başkaları ile sorunlarını onlarla konuşarak çözer.”, (K17G2) "Arkadaşlarıyla sorunlarını çözemediği zamanlarda yetişkinlerden yardım ister." ve (K17G3) "Gerekli zamanlarda uzlaşmacı davranır." göstergelerine resimli çocuk kitaplarının içerik ögelerinde yer verilmiştir. Resim ögelerinde de (K17G1) "Başkaları ile sorunlarını onlarla konuşarak çözer." (K17G2) “Arkadaşlarıyla sorunlarını çözemediği zamanlarda yetişkinlerden yardım ister.” ve 
5-6 Yaş Resimli Çocuk Kitaplarındaki Resim ve İçerik Ögelerinin MEB Okul Öncesi Eğitim Programı SosyalDuygusal Alan Kazanım ve Göstergeler Açısından İncelenmesi

Analysis of the Picture and Content Items of the Children's Picture Book for 5-6 Years Old in terms of SocialEmotional Field Outcomes and Indicators in MEB Preschool Education Program

269

(K17G3) “Gerekli zamanlarda uzlaşmacı davranır.” göstergelerine yer verilmiştir. Çocukların çatışma anlarında kendilerini rahatsız eden hareketlere uygun karşılık vermesi ve kendi kendini yönetebilmesi, okul öncesi dönem için önemli olan sosyal beceriler içerisinde yer almaktadır (Gresham ve Elliott, 1990; akt. Kamaraj, 2004). Bu nedenle resimli çocuk kitaplarında (K17) "Başkalarıyla sorunlarını çözer." kazanımına çocukların başkalarıyla sorunlarını çözebilme becerilerini geliştirebilmeleri açısından daha çok yer verilmesinin önemli olduğu düşünülmektedir.

\section{Sonuç}

Bu çalışmada, 60-72 ay okul öncesi dönem resimli çocuk kitaplarındaki resim ve içerik ögeleri MEB 2013 Okul Öncesi Eğitim Programı sosyal-duygusal alan kazanım ve göstergeleri açısından incelenmiştir. Çalışmanın sonucunda 60-72 aylık resimli çocuk kitaplarında sosyalduygusal alan kazanım ve göstergelerine içerik ögelerinde yer veren 477 yazılı ifade, resim ögelerinde yer veren 397 görsel ifade bulunmuştur.

Yapılan çalışma sonucunda resimli çocuk kitaplarının içerik ögelerinde (K4) "Bir olay ya da durumla ilgili olarak başkalarının duygularını açıklar." kazanımının \%20,34 oranında ilk sırada yer aldığı tespit edilmiştir. İncelenen resimli çocuk kitaplarının içerik ögelerinde (K1. G4) "Duyuşsal özelliklerini söyler." göstergesinin ise \%10,48 oranında ilk sırada yer aldığ tespit edilmiştir.

Resimli çocuk kitaplarının içerik ögelerinde (K11) “Atatürk ile ilgili etkinliklerde sorumluluk alır." kazanımına yer verilmediği tespit edilmiştir. İncelenen resimli çocuk kitaplarının içerik ögelerinde 10 göstergeye (K1G2, K2G2, K2G3, K9G1, K9G2, K11G1, K11G2, K12G1, K14G3, K16G2) yer verilmediği tespit edilmiştir.

Yapılan çalışma sonucunda resimli çocuk kitaplarının resim ögelerinde (K4) "Bir olay ya da durumla ilgili olarak başkalarının duygularını açıklar." kazanımının \%22,41 oranında ilk sırada yer aldığı tespit edilmiştir. İncelenen resimli çocuk kitaplarının resim ögelerinde (K1. G4) "Duyuşsal özelliklerini söyler." göstergesinin ise \%12,34 oranında ilk sırada yer aldığ1 tespit edilmiştir.

Resimli çocuk kitaplarının resim ögelerinde (K2) "Ailesiyle ilgili özellikleri tanıtır.", (K9) "Farklı kültürel özellikleri söyler.” ve (K11) “Atatürk ile ilgili etkinliklerde sorumluluk alır." kazanımlarına yer verilmediği tespit edilmiştir. İncelenen resimli çocuk kitaplarının resim ögelerinde 16 göstergeye (K1G2, K2G1, K2G2, K2G3, K2G4, K2G5, K6G1, K9G1, K9G2, K9G3, K10G3, K11G1, K11G2, K12G3, K15G1, K16G2) yer verilmediği tespit edilmiştir.

(K4) "Bir olay ya da durumla ilgili olarak başkalarının duygularını açıklar." kazanımının hem resim hem de içerik ögeleri açısından incelenen resimli çocuk kitaplarında en çok bulunan kazanım olduğu sonucuna ulaşılmıştır. (K1. G4) “Duyuşsal özelliklerini söyler.” göstergesinin ise hem resim hem de içerik ögeleri açısından incelenen resimli çocuk kitaplarında en çok bulunan gösterge olduğu sonucuna ulaşılmıştır. (K11) "Atatürk ile ilgili etkinliklerde sorumluluk alır." kazanımının hem resim hem de içerik ögeleri açısından incelenen resimli çocuk kitaplarında yer verilmeyen kazanım olduğu sonucuna ulaşılmıştır. Hem resim hem de içerik ögeleri açısından incelenen resimli çocuk kitaplarında 8 göstergeye (K1G2, K2G2, K2G3, K9G1, K9G2, K11G1, K11G2, K16G2) yer verilmediği sonucuna ulaşılmıştır. 


\section{Öneriler}

- Resimli çocuk kitaplarını oluşturan yazarların, resimleyenlerin, editörlerin ve yayınevlerinin MEB 2013 Okul Öncesi Eğitim Programı'nda bulunan gelişim alanları, kazanım-göstergeler hakkında bilgi sahibi olmalarının önemli olduğu düşünülmektedir. $\mathrm{Bu}$ doğrultuda kitapları tasarlayan kişiler resimli çocuk kitaplarını programı destekleyecek nitelikte oluşturmalıdır. Yayınlanan çocuk kitaplarının tanıtımını yapmaları, ilgili kişileri gündemden haberdar etmeleri önerilmektedir.

- Resimli çocuk kitaplarının resim ve içerik ögelerinin bilişsel, dil, motor gelişim alanlarında ve öz bakım becerilerinde bulunan kazanım-göstergeler bakımından değerlendirilmesi önerilebilir. Böylece MEB 2013 Okul Öncesi Eğitim Programı'ndaki gelişim alanlarının resimli çocuk kitaplarında desteklenmesine yönelik bütüncül bir değerlendirme yapılabilir.

- Sosyal-duygusal alanın gelişimine verilen önemin her geçen gün artması sebebiyle sosyal-duygusal alanda çocuk kitapları inceleme araştırmalarının ve bu alanda yapılan farklı araştırmaların sayılarının arttırılmasının ilgili alan yazına büyük katkılar sağlayacağı düşünülmektedir.

- Erken çocukluk dönemindeki çocuklar için yazılan kitaplarda içerik ögelerinin yanı sıra resim ögelerinin de anlatılan konuyu doğru yansıtması ve çocukların gelişim düzeyine uygun olması önem teşkil etmektedir. Bu yüzden çocuk kitaplarını resimleyen kişilerin bu hususlara çok dikkat etmeleri ve imkânlar çerçevesinde kitapların hitap ettiği yaş grubunun özelliklerini ve ihtiyaçlarını içeren eğitimlerden geçmeleri önerilmektedir.

- Yapılan çalışmada resimli çocuk kitaplarının resim ve içerik ögelerinde (K3) "Kendini yaratıcı yollarla ifade eder." kazanımına çok fazla yer verilmediği görülmüştür. Bu sebeple çocukların farklı düşünme becerilerini destekleyecek, yaratıcılığına katkı sağlayacak nitelikli resimli çocuk kitaplarının artırılması önerilmektedir.

- Yapılan çalışmada resimli çocuk kitaplarının resim ögelerinde "Ailesiyle ilgili özellikleri tanıtır.", "Farklı kültürel özellikleri söyler." ve "Atatürk ile ilgili etkinliklerde sorumluluk alır." kazanımlarına hiç yer verilmemesi dikkat çekmektedir. Resimli çocuk kitaplarında sıklıkla yer verilen kazanımlar gibi hiç yer verilmeyen kazanımları içeren kitap sayılarının arttırılması çocukların benlik bilinçlerinin ve kişisel gelişimlerinin desteklenmesi açısından olumlu değişikliklere yol açacağı düşünülmektedir.

- Millî Eğitim Bakanlığı'nın okul öncesi dönem çocukları adına Atatürk hakkında bir bilinç oluşturma hedefi, üzerinde durulması gereken önemli bir konudur. Resimli çocuk kitapları arasında çocukların sıklıkla ulaşabilecekleri şekilde Atatürk ile ilgili nitelikli kitapların artırılması önerilmektedir.

- Kütüphaneye kitap seçen kişilerin, çocukların gelişimini destekleyici nitelikte yayınları seçebilmeleri için alanda gerekli bilgi ve donanıma sahip olmaları önerilmektedir.

\section{Kaynakça}

Aral, N. (2008). Erken çocukluk dönemi ve kitap. M. Kaplan (Yay. Hazl.), Türk Halkları Edebiyatı II. Uluslararası Çocuk Edebiyatı Kongresi Bildiri Kitabı I (ss. 471-475) içinde. Kafkas Üniversitesi.

Aram, D. ve Aviram, S. (2009). Mothers' storybook reading and kindergartners' socio-emotional and literacy development. Reading Psychology, 30(2), 175-194. 
5-6 Yaş Resimli Çocuk Kitaplarındaki Resim ve İçerik Ögelerinin MEB Okul Öncesi Eğitim Programı SosyalDuygusal Alan Kazanım ve Göstergeler Açısından İncelenmesi

Analysis of the Picture and Content Items of the Children's Picture Book for 5-6 Years Old in terms of Social-

Aram, D. ve Levin, I. (2002). Mother-child joint writing and storybook reading: Relations with literacy among low SES kindergarteners. Merrill-Palmer Quarterly, 48, 202-224.

Baş, B. (2015). Türkçe öğretimi açısından çocuk edebiyatı (2. bs.). Pegem Yayınevi.

Benic, M. Z., Herzog, J. ve Susic, B. B. (2017). Early childhood education students' self-assessment of their teaching competences in the arts. New Trends and Issues Proceedings on Humanities and Social Sciences, 4(6), 066-078.

Bennett, K. K., Weigel, D. J. ve Martin, S. S. (2002). Children's acquisition of early literacy skills: Examining family contributions. Early Childhood Research Quarterly, 17(3), 295-317.

Bilgin, H. (2011). 5-6 yaş çocuklarına yönelik 1990-2010 yılları arasında basılan resimli kitapların çocuğa görelik kavramına göre incelenmesi [Yüksek lisans tezi]. Marmara Üniversitesi. https://katalog.marmara.edu.tr/eyayin/tez/T0081003.pdf

Bulut, P. ve Kuşdemir, Y. (2013). TÜBİTAK tarafından yayınlanan çocuk kitaplarının içerik özelliklerinin incelenmesi. Turkish Studies, 8(12), 215-226.

Court, D. ve Rosental, E. (2007). Values embodied in children's literature used in early childhood education in Israeli state schools. Early Childhood Education Journal, 34(6), 407-414.

Çakmak Güleç, H. ve Geçgel, H. (2006). Çocuk edebiyatı. Kök Yayıncılık.

Çakmak Güleç, H. ve Geçgel, H. (2015). Çocuk edebiyatı okul öncesinde edebiyat ve kitap. Paradigma Akademi Yayınları.

Çılgın, A. S. (2006). Çocuğa büyülü bir dünyanın kapılarını açmak. Milli Eğitim Dergisi, 172, 175-18.

Demircan, C. (2006). Türkiye'deki çocuk kütüphanelerinin halk kütüphanelerine devredilmelerinden önceki niceliksel durum 1995-2000. Türk Kütüphaneciliği, 20(2) , 177-194.

Denzin, N. K. ve Lincoln, Y. S. (Yay. Hazl.). (2008). The landscape of qualitative research (3. bs.). Sage Publications

Dirican, R. ve Dağlığlu, H. (2014). 3-6 yaş grubu çocuklarına yönelik yayımlanan resimli hikaye kitaplarının bazı temel değerler açısından incelenmesi. Cumhuriyet Uluslararası Eğitim Dergisi, 3(2), 44-69. doi:10.30703/cije.321341

Eliason. C. ve Jenkins, L. (2003). A practical guide to early childhood curriculum. Merrill Prentice Hall.

Farris, P. J. ve Fuhler, C. J. (1994). Developing social studies concepts through picture books. The Reading Teacher, 47(5), 380-387.

Fox, J. E. ve Schirrmacher, R. (2014). Çocuklarda sanat ve yaratıcılığın gelişsimi (E. Durulalp, Çev.). Nobel Akademik Yayıncılık.

Garner, P. W. ve Spears, F. M. (2000). Emotion regulation in low-income preschoolers. Social Development, 9(2), 246-264.

Gönen, M. ve Yılmaz, A. (2018). Halk kütüphanelerindeki resimli çocuk kitaplarının konu yönünden incelenmesi. A. Kakırman Yıldız ve L. Özdemir (Yay. Hazl.). 1. Uluslararası Çocuk Kütüphaneleri Sempozyumu Bildirileri (ss. 89-104) içinde. Kültür ve Turizm Bakanlığı. http://www.cocukkutuphaneleri.org/wp-content/uploads/2019/06/bildiri-kitab\%C4\%B1.pdf

Gönen, M., Katranc1, M., Uygun, M. ve Uçuş, Ş. (2011). İlköğretim birinci kademe öğrencilerine yönelik çocuk kitaplarının, içerik, resimleme ve fiziksel özellikleri açısından incelenmesi. Ĕgitim ve Bilim, 36(160), 250-265.

Gönen, M., Yazıcı, D., Aydos, E. H., Öztürk, M. ve Akbaş, S. (2014). Examination of picture story books in terms of language-cognitive development area indicator and concepts in moe 2013 Early Childhood Education Program. Asian Conference on Education Official Conference Proceedings. (ss. 39-50) içinde. The International Academic Forum. 
Gresham, F. M. ve Elliott, S. N. (1990). Social skills rating system. American Guidance Service.

Güleryüz, H. (2006). Yaratıcı çocuk edebiyatı. Pegem-A Yayıncılık.

Gülpınar, F. (2010). Görsel kavramlar, illüstrasyon ve çocuk kitapları [Yüksek lisans tezi, Haliç Üniversitesi].

https://tez.yok.gov.tr/UlusalTezMerkezi/TezGoster?key=ZeTyprYuef2HkaF3xt4wYuKYCuIeut ZEBwa_wQbBISfW9xcbASyg0rp_Eum78r6J

Huck, C. S. ve Kiefer B. Z. (2003). Children's litarature in the elemantary school (8. bs.). McGraw Hill Books.

İbiş, E. (2017). Değerler eğitimi temelli yaratıcı drama programının 5-6 yaş çocuklarının sosyal becerilerinin gelişimine etkisi [Yüksek lisans tezi, Dokuz Eylül Üniversitesi]. https://tez.yok.gov.tr/UlusalTezMerkezi/TezGoster?key=RrI-Krk3A-RkF4YfHofuk5eu4AMh_ UteU9H8A3sWUpHLO0ToT9VcoKKGUfIZSKmK

İş, A. (2017). Okul öncesi ve sını öğretmenlerinin 2013 okul öncesi eğitim programındaki kazanımların gerçekleşme düzeyine yönelik algıları [Yüksek lisans tezi, Fırat Üniversitesi]. https://tez.yok.gov.tr/UlusalTezMerkezi/TezGoster?key=DPTyuy3wRPq_qvCPSqUB61TwXG EaphsC_biLqjONBJnDUSI-iaawz5P4QIVWMDM9

Jones, D. E., Greenberg, M. ve Crowley, M. (2015). Early social-emotional functioning and public health: The relationship between kindergarten social competence and future wellness. American Journal Of Public Health, 105(11), 2283-2290.

Kağıtçıbaşı, Ç. (2007). Kültürel psikoloji-kültür bağlamında insan ve aile. Evrim Yayınları.

Kamaraj, I. (2004). Sosyal becerileri derecelendirme ölçeğinin Türkçeye uyarlanması ve beş yaş çocuklarının atılganlık sosyal becerisini kazanmalarında eğitici drama programının etkisi [Yayınlanmamış doktora tezi]. Marmara Üniversitesi.

Kandır, A. ve Alpan, U. Y. (2008). Okul öncesi dönemde sosyal-duygusal gelişime anne-baba davranışlarının etkisi. Sosyal Politika Çalışmaları Dergisi, 14(14), 33-38.

Kapıkıran, N. A., İvrendi, A. B. ve Adak, A. (2006). Okul öncesi çocuklarında sosyal beceri: Durum saptaması. Pamukkale Üniversitesi Eğitim Fakültesi Dergisi, 19(19), 19-27.

Kılınçc1, E. ve Can, B. (2020). Analysis of the characters in illustrated children's books in terms of social and emotional skills. Inonu University Journal of the Faculty of Education, 21(3), 1216-1234. doi:10.17679/inuefd.719309

Kızıltaş, E., Ertör, E. ve Karademir, A. (2018). Okul öncesi öğretmenlerinin hazırladıkları etkinlik planlarında sosyal ve duygusal gelişim alanına yer verme düzeyi. Mediterranean Journal of Humanities, 8(1), 247- 257. doi:10.13114/MJH.2018.395

Leming, J. (2000). Tell me a story: An evaluation of a literature-based character education programme. Journal of Moral Education, 29(4), 413-427. doi:10.1080/713679388

Mendoza, J. ve Reese, D. (2001). Examining multicultural picture books for early childhood classroom: Possibilities and pitfalls. Early Childhood Research \& Practice, 3, 1-38.

Miles, M, B. ve Huberman, A. M. (1994). Qualitative data analysis: an expanded sourcebook. (2. bs.). Sage.

Milli Eğitim Bakanlı̆̆ı (MEB). (2013). Okul öncesi eğitim programı. http://tegm.meb.gov.tr/dosya/okuloncesi/ooproram.pdf

Özen, B. (2020). Almanya'da 2010-2017 yılları arasında yayınlanan 3-6 yaş arası resimli çocuk kitaplarında bireysel farkllliklar [Doktora tezi, Trakya Üniversitesi]. https://tez.yok.gov.tr/UlusalTezMerkezi/TezGoster?key=_F5QEpayDXGqGZlp9XiFtEqz4vrm NvHqVq6S9CEu1xUT45u2XF7n0X94LqIpfIYJ 
5-6 Yaş Resimli Çocuk Kitaplarındaki Resim ve İçerik Ögelerinin MEB Okul Öncesi Eğitim Programı SosyalDuygusal Alan Kazanım ve Göstergeler Açısından İncelenmesi

Analysis of the Picture and Content Items of the Children's Picture Book for 5-6 Years Old in terms of Social-

Emotional Field Outcomes and Indicators in MEB Preschool Education Program

Pekdoğan, S. (2017). 3-6 Yaş çocuğa sahip ebeveynlerin resimli çocuk kitapları ölçütlerinin incelenmesi. Ekev Akademi Dergisi, 21(71) 315-326.

Saarni, C. (1999). The development of emotional competence. Guilford Pres.

Sandelowski, M. (1986). The problem of rigor in qualitative research. Advances in Nursing Science, $8(3), 27-37$.

Sapsağlam, Ö. (2020). Okul öncesi eğitim programlarının milli kavramlar açısından incelenmesi. Türkiye Ĕ̈itim Dergisi, 5(1), 1-17.

Sever, S. (2005). Çocuk, yazın ve yaşam. Çoluk Çocuk Dergisi, 1, 30-34.

Sever, S. (2013). Çocuk edebiyatı ve okuma kültürü. Tudem.

Sildir, E. (2016). Okul öncesi döneme yönelik hikâye kitaplarının Milli Eğitim Bakanllğı 2013 okul öncesi eğitim programında yer alan sosyal duygusal alan gelişimle ilgili kazanımları desteklemeleri yönünden incelenmesi [Yüksek lisans tezi, Gazi Üniversitesi]. https://tez.yok.gov.tr/UlusalTezMerkezi/TezGoster?key=Br_XTptK8CZ70f0JGX9xErYvElo2nf oHugX3souuW8vsLcY3U_NMPtOxd1wrr9B9

Sildir, E. ve Tüfekci Akcan, A, S. (2018). Öykü kitaplarının sosyal-duygusal alan kazanımlarını desteklemeleri yönünden incelenmesi. Eğitim ve Toplum Araştırmaları Dergisi, 5(1), 265-286.

Şirin, M. R. (1998). 99 Soruda çocuk edebiyatı (2. bs.). Çocuk Vakfı Yayınları.

Tanju, E. H. (2010). Çocuklarda kitap okuma alışkanlığına genel bir bakış. Sosyal Politika Çalışmaları Dergisi, 21(21), 30-39.

Temple, C., Martinez, M. ve Yokota, J. (2006). Childrens books in childrens hands: an introduction to their literature (3. bs.). Allyn and Bacon.

Turgut Bayram, Z. (2009). Resimli çocuk kitaplarının okuma alışkanlığı üzerindeki etkisi [Yüksek lisans tezi, İstanbul Üniversitesi]. https://tez.yok.gov.tr/UlusalTezMerkezi/TezGoster?key =ZeTyprYuef2HkaF3xt4wYi-wbiOk9HT2_IbfL_S8zdNc_pNVhpbJXIdXeONqUWAs

Tür, G. ve Turla, A. (1999). Okul öncesinde çocuk, edebiyat ve kitap. YA-PA Yayınları.

Ural, S. (2013). Okul öncesi çocuk kitaplarının tanımı. M. Gönen (Yay. Hazl.), Çocuk edebiyatı (ss. 3355) içinde. Eğiten Kitap.

Veziroğlu, M. (2009). Resimli çocuk kitaplarının MEB okul öncesi eğitim programındaki kazanımlara uygunluğunun incelenmesi [Yüksek lisans tezi, Hacettepe Üniversitesi]. https://tez.yok.gov.tr/UlusalTezMerkezi/TezGoster?key=NtBAevXNhYaNqJFoAcdBdphJrZA_48RPqU_fp9_ghvx7v2jp17nbh_OIjZdHtq_

Veziroğlu, M. ve Gönen, M. (2012). Resimli çocuk kitaplarının M.E.B. Okul Öncesi Eğitim Programı'ndaki kazanımlara uygunluğunun incelenmesi. Ĕ̌itim ve Bilim, 37(163), 226 - 238.

Yazıcı, D., Yıldız, C. ve Durmuşoğlu, M.C. (2018). Erken çocukluk dönemi resimli çocuk kitaplarının eğitsel özelliklerinin incelenmesi. Abant İzzet Baysal Üniversitesi Eğitim Fakültesi Dergisi, 18(2), 1196-1209.

Yıldırım, A. ve Şimsek, H. (2011). Sosyal bilimlerde nitel araştırma yöntemleri (8. bs.). Seçkin Yayıncilik.

Yıldırım, A. ve Şimşek, H. (2016). Sosyal bilimlerde nitel araştırma yöntemleri (Gnşl. 10. bs.). Seçkin Yayıncilik. 